\title{
Lactarius subsectio Scrobiculati in NW Europe
}

\author{
ILKKA KYTÖVUORI
}

\begin{abstract}
KYTÖVUORI, I. 1984: Lactarius subsectio Scrobiculati in NW Europe. - Karstenia 24: $41-72$.

Eight species are recognized in the subsection Scrobiculati in NW Europe: Lactarius scrobiculatus (Scop.: Fr.) Fr., L. leonis Kytöv., L. olivinus Kytöv., L. tuomikoskii Kytöv., L. auriolla Kytöv., L. resimus (Fr.) Fr., L. aquizonatus Kytöv. and L. citriolens Pouzar. Five of them are new and are described here. The distribution of each species in NW Europe is mapped, and their ecology and relationships are discussed.
\end{abstract}

Ilkka Kytövuori, Department of Botany, University of Helsinki, Unioninkatu 44, SF00170 Helsinki, Finland

Although the genus Lactarius has been dealt with extensively by earlier writers, particularly Neuhoff (1956) and Hesler \& Smith (1979), it still poses a number of problems. The Finnish Lactarius species were treated by Tuomikoski $(1952,1953)$ and since then this has been one of the best-known Agaric genera in Fennoscandia. From Tuomikoski's comments on his herbarium specimens in Helsinki $(\mathrm{H})$, it is evident that he noted a lack of taxonomical uniformity in L. scrobiculatus in Finland. Some new aspects of the group became clear to me in the field during the good mushroom season in northern Scandinavia in 1979, but subsequent studies showed the group to be surprisingly complicated and revealed eight mainly boreal species, instead of the two or three commonly recognized. My preliminary observations were first given orally in a symposium arranged in honour of Prof. Risto Tuomikoski's 70th anniversary in .January 1981.

\section{Materials and methods}

Field work was done by the author in Finland, Sweden and Norway during the years 1979-1983 (herbarium material in $\mathrm{H})$, and material was checked in the following herbaria: $\mathrm{BG}$, C, GB, H, KUO, LD, O, OULU, PRM, S, TAA, TRH, TUR, UPS (the symbols according to Holmgren et al. 1981). Type material and some other specimens were examined from BPI, MICH, NY, NYS and VPI.

Microscopical characters were examined with the microscope Leiz Laborlux 12 at magnifications of about 625 and 1560. Spores and cystidia were drawn with the Leitz drawing tube at a magnification of 2000. Spores were examined, measured (with the ocular micrometer) and drawn from slides showing the surface view of pieces of gills from dried basidiocarps, mounted in Melzer's reagent. The tops of cystidia were examined from the same slides. Only spores in horizontal position were measured; young, anomalous, very small and gigantic spores were excluded. The spore surface ornamentation was excluded in the measurements; length and width were measured from the same spore and the lenght/ width ratios calculated for individual spores.

Cystidia were drawn from tangential sections of the pi- leus. Thin radial pieces of dried basidiocarp were moistened with $94 \%$ ethanol, soaked in water, blotted with a paper towel and sectioned transversely with a razor blade using polystyrene to support the material. The sections were mounted in Melzer's reagent. The length of the cystidia was measured from the point where the lactifer turns outwards from the gill trama to form a macrocystidium, or where a clear constriction or transverse wall is found (cf. Figs. 2027). Often this point is not exact. The projecting part was measured outwards from the \pm continuous plane formed by the outher ends of the basidioles.

The colour changes of the latex were tested with $30 \%$ $\mathrm{KOH}$. The pileus colour is described according to Kornerup \& Wanscher (1961), the vegetation zones of Fennoscandia are given according to Ahti et al. (1968) and the biogeographical provinces according to Lid (1979) and Korhonen (1984). The descriptive terminology is according to Hesler \& Smith (1979) and Snell \& Dick (1971). For a survey of the geology of Fennoscandia, see Hultén (1971: 38).

The illustrations are my own, unless otherwise stated. The photographs of the fruit bodies represent fresh specimens.

\section{Lactarius subsectio Scrobiculati}

Lactarius subg. Piperites sectio Piperites subsectio Scrobiculati Hesler \& A.H. Smith, N. Amer. Lactarius: 285. 1979.

Lactarius sectio Eulactarius subsectio Claricolorini Gruppe Resimus Neuhoff, Milchlinge: 66, 104. 1956 (nom. inval.).

Lactarius sectio Scrobiculus subsectio Scrobiculus ('Scrobiculi') Hesler \& H.A. Smith, Brittonia 12: 310. 1960.

Lactarius subgenus Lactarius sectio Tricholomoidei subsectio Scrobiculini Bon, Doc. Mycol. 40: 22. 1980 (nov. inval.).

Size large to medium, pileus convex-depressed to infundibuliform, yellow to white, slimy. Stipe rather short, scrobiculate or not, dry. Macrocystidia abundant to nearly absent, large macrocystidioid cheilocystidia absent. Pileus cuticle a fairly thick ixocutis. Latex white, rapidly turning sulphur yellow when exposed, acrid.

\section{Key to species}

1 White to yellowish, pileus azonate or marginally with narrow watery zones .................................................................... 6 
- Yellow to pale yellow, pileus azonate or with darker pigmented zones ....................................................................... 2

2 Stipe not spotted or spots restricted to very base .......... 4

- Stipe spotted up to the top (sometimes indistinctly) .... 3

3 Hard, robust, yellow, pileus zonate, margin roughly tomentose, macrocystidia nearly absent (projecting less than the basidia), spores broadly ellipsoid, not reticulate 1. L. scrobiculatus

- Softer, yellow whitish to pale yellow, pileus indistinctly zonate, margin woolly, macrocystidia long, spores subglobose, nearly reticulate ……………………. 2. L. leonis

4 Greenish yellow, macrocystidia abundant, more than 10 $\mu \mathrm{m}$ wide .................................................... 3. L. olivinus

- Without greenish tint, macrocystidia scattered, less than $10 \mu \mathrm{m}$ wide

5 Pileus infundibuliform, margin with gelatinous hairs, lamellae straight, usually not forked near the stipe, spores $7.3-9.1 \times 5.4-6.6 \mu \mathrm{m}$, broadly ellipsoid to ellipsoid 5. L. auriolla

- Pileus plano-depressed, young margin with hairs, which later form radial ridges on the marginal surface, lamellae flexuose, forked near the stipe, spores $7.7-10.2 \times 6.3-$ 7.7. $\mu \mathrm{m}$, broadly ellipsoid. ..................... 4. L. tuomikoskii

6 Pileus marginally tomentose, azonate or with a few watery zones at the very edge, spores $7.7-10 \times 5.7-7 \mu \mathrm{m}$ 6. L. resimus

- Pileus margin and marginal surface bearded or scaly, watery zones more extensive, spores smaller ………....... 7

7 Scales or hairs gelatinous, lamellae crowded, with salmon tint, spores 6.8.-8.8 $\times 4.8-6.1 \mu \mathrm{m}$, ellipsoid, reticulate ....................................................... 7. L. aquizonatus

- Hard, robust, hairs not gelatinous, lamellae subdistant, buff, spores $7-8.4 \times 5.4-6.6 \mu \mathrm{m}$, broadly ellipsoid, not reticulate ……............................................ 8. L. citriolens

\section{Yellow group}

Large to medium-sized, pileus convex, \pm deeply depressed in the centre, yellow to whitish yellow, azonate or zonate with darker pigmented zones near the centre, watery zones \pm absent. Spite scrobiculate or not, not very short. Macrocystidia abundant to nearly absent often large. Only with Picea abies, most often in moist habitats.

\section{Lactarius scrobiculatus (Scop.: Fr.) Fr.}

Lactarius scrobiculatus (Scop.: Fr.) Fr., Epicr. Syst. Mycol.: 334. 1836. - Agaricus scrobiculatus Scop., Fl. Carn.: 450. 1772. - Type: not typified.

Agaricus thejogalus var. luteus Alb. \& Schweiniz, Consp. Fung.: 208. 1805 .

A. intermedius Fr., Obs. Mycol. I: 57. 1815.

Illustrations. Schaeffer (1774 p.p.), Krombholz (1843, s.n. A. intermedius, not s.n. A. scrobiculatus), Ricken (1915), Bresadola (1928), Neuhoff (1956), Pilát \& Ušák (1959), Tuomikoski (1971), Mossberg et al. (1977), Kalamees (1979), Cetto (1979), Dähncke \& Dähncke (1980), Marchand (1980), Michael et al. (1983), Korhonen (1984). - Not Hesler \& Smith (1960).

Large and robust. Pileus $6-20(-25) \mathrm{cm}$ wide, convex-depressed to plano-depressed with edge compactly inrolled; slimy. The inrolled margin with broad cover of dense short hairs (not exceeding $1 \mathrm{~mm}$ ), (nearly) glabrous when outrolled. Colour light yellow, ochraceous to brownish yellow, clearly zonate with more brownish, sometimes greenish brown, zones, darkest in the centre. Context thick, hard. Latex abundant, white rapidly turning sulphur yellow when exposed, orange in $\mathrm{KOH}$, acrid to burning acrid.
Lamellae close, straight, usually not forked near stipe, adnate to slightly decurrent, whitish, the gill edge brownish ochraceous, often spotted, lamellulae numerous.

Stipe relatively stout, $3-9 \mathrm{~cm}$ long, $2-6 \mathrm{~cm}$ thick, hard, of even thickness, subradicating, dry, scrobiculate with unequal depressed spots on whitish, pruinose background. At the base the scrobiculae with a rim of coarse, rusty brown hairs (Fig. 1g). The top of the stipe white, tometose, the tomentum continuing up between the lamellae.

Spores $8.2-9.5 \times 6.1-7.3 \mu \mathrm{m}$, lenght/width ratio $1.23-1.38$, broadly ellipsoid, with a myloid ornamentation of some long, narrow ridges, and/or numerous shorter fragments, and isolated warts, not forming even a broken reticulum, prominences up to $1 \mu \mathrm{m}$ high, higher than broad, plage fairly large. Mounted spores fairly light-coloured.

Basidia 37-47 $\times 8-11 \mu \mathrm{m}, 4$-spored. Macrocystidia rare, between the gills only, $32-46 \times 5-7 \mu \mathrm{m}$, imbedded or slightly projecting (up to $12 \mu \mathrm{m}$ ), with the broadest point in the hymenium. Pseudocystidia fairly abundant, $6-10 \mu \mathrm{m}$ thick.

In Fennoscandia calcicolous, growing in rich, spruce-dominated grass-herb forest and in moist, often spring-fed, spruce-hardwood swamps. Often gregarious. Only with Picea abies. Mainly boreal to hemiboreal, common in calcareous regions. August to November.

\section{Distribution and ecology}

L. scrobiculatus is a rather exacting and calcicolous species in Fennoscandia. In Finland it is fairly common only in some restricted areas in Alland (Ahvenanmaa) and the Lohja region in the south, and in the Kemi-Tornio region and Kuusamo in the north. Fig. 2 gives a slightly misleading picture, as most of the localities are very resricted, often around small (usually a few $\mathrm{m}^{2}$ wide), abandoned limestone quarries systematically checked by the author. Owing to this fact, and the long fruiting pediod (cf. Fig. 17) of the species, the occurrence of $L$. scrobiculatus in southern Finland is clearly overemphasized on the map as compared with the other yellow species treated here. In most regions in Finland the species is absent or very rare. The reports in the literature, e.g. Tuomikoski (1952, 1953, 1971), Hintikka (in Lange 1964), Ahti (1975), also include the following four species, especially L. tuomikoskii, and are thus not reliable. Tuomiskoski's (1943) report of L. scrobiculatus from the rich forest area of Sortavala on the Karelian A.S.S.R. clearly relates to the present species (judging from his excellent description).

In Scandinavia L. scrobiculatus is common (the commonest species of the group) in the regions of schistose Caledonian and Cambro-Silurian bedrock (cf. Hultén 1971: 38), occurring south of and below the northern and upper limits of Picea abies. On crystalline Precambrian bedrock, it is confined to local occurrences of calcareous rocks or soil.

In Central Europe L. scrobiculatus is common and abundant in the mountains, but rare in the lowlands (cf. Neuhoff 1956). It has also been reported from Asia Minor (Neuhoff 1956, Watling \& Gregory 1977), 

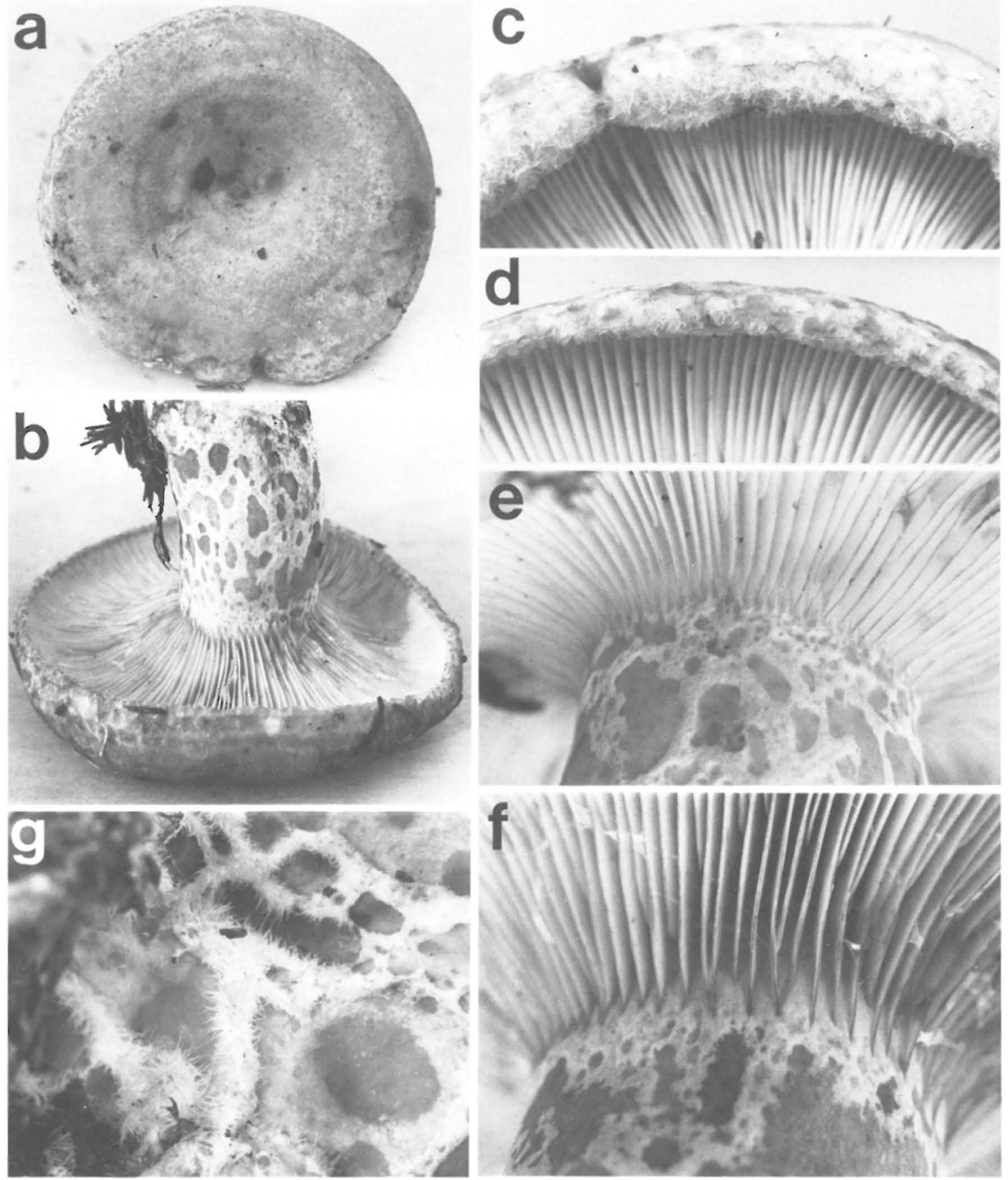

Fig. 1. Lactarius scrobiculatus. - a, c-e) Ky $82176,-\mathrm{b}, \mathrm{f}, \mathrm{g}) \mathrm{Ky} 81616 .-\mathrm{g}$ ) Hairs edging the scrobiculi at the base of the stipe (base towards the left).

but the reports are based on specimens (Pilát: Iter orientale 1931: no. 625 PRM, Uotila 20070, 20072 H) not belonging to $L$. scrobiculatus in the present sense. Vasil'eva (1973) has recorded the species from the Far East. From North America it has been reported many times (e.g. Burlingham 1908, 1910, Neuhoff 1956 , Hesler \& Smith 1960, Pomerleau 1980), but all the records seem to have been based on erroneous interpretations of the species; this fact was also noted by Hesler \& Smith (1979). 


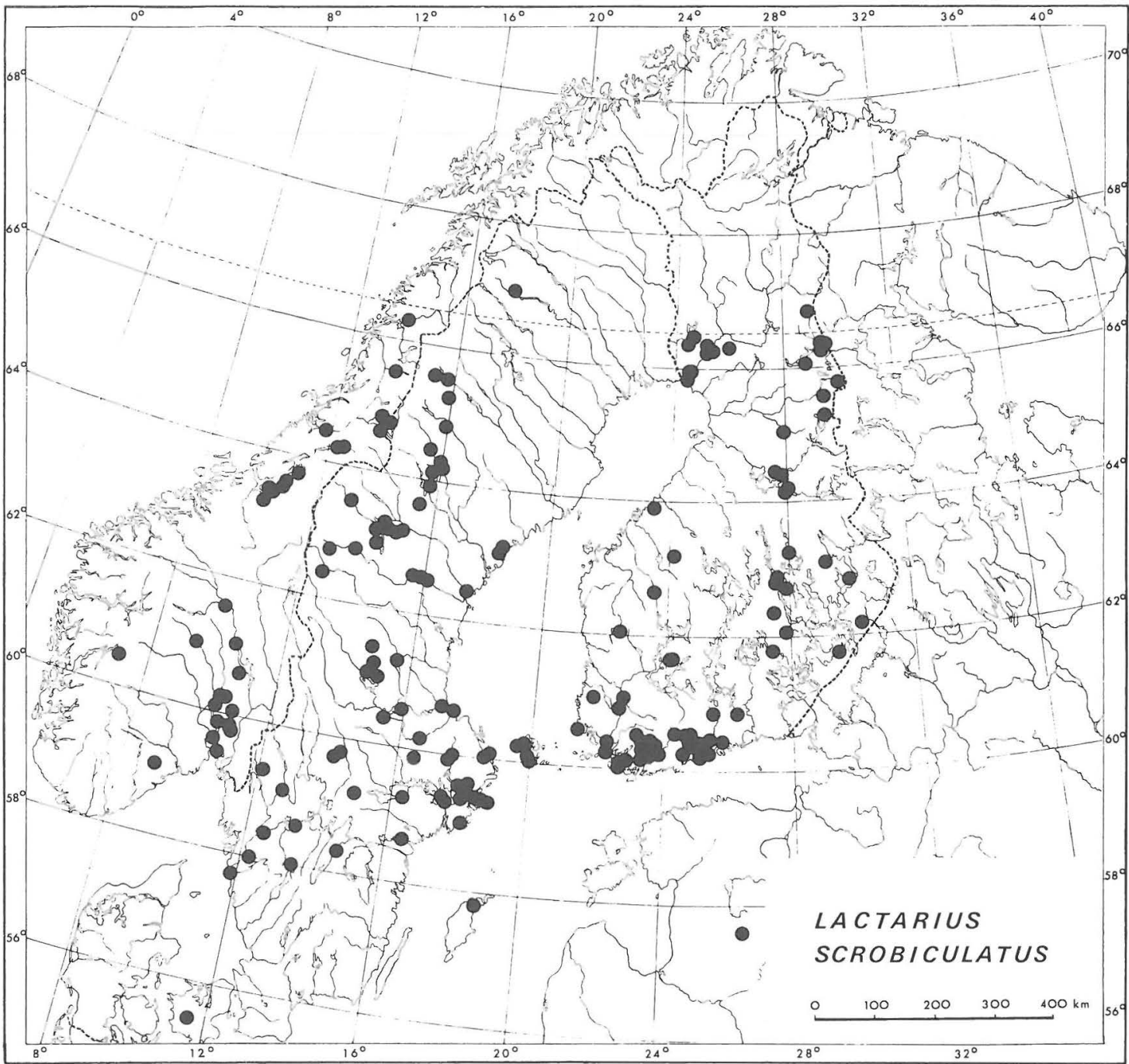

Fig. 2. Distribution of Lactarius scrobiculatus in NW Europe according to the material examined.

L. scrobiculatus seems to grow only with Picea abies. In Fennoscandia, it is common in edaphically suitable habitats throughout the boreal and hemiboreal zones. In the latter zone it is clearly the commonest species of the yellow group. In the temperate zone it is absent or very rare (Neuhoff 1956). In regions with favourable habitats it may extend up to the upper oroboreal zone, even to the uppermost spruce woods.

In the southern part of Fennoscandia L. scrobiculatus grows in dryish grass-herb forests dominated by spruce or hardwood trees or in thickets below rock faces. A thin humus layer and weak moss cover are characteristic of such habitats. In coniferous forests with a thicker humus layer and continuous moss cover it grows only in or by depressions with moving nutrient-rich water and somewhat swampy vegetation. In the north the habitats are mostly spruce-hard- wood swamps in forest depressions, at margins of eutrophic fens, around springs and along brooks and rivers.

\section{Phenology}

In Fennoscandia the production of fruit bodies of $L$. scrobiculatus begins in late July - early August, reaching a peak in late August and September (Fig. 17). The large colonies characteristic of the species contain basidiocarps of widely varying age. New ones keep developing, while others slowly decay. In southern Finland production cases at about the end of September. Owing to the hard context, decay is slow and moribund basidiocarps can be collected for some time. L. scrobiculatus is not sensitive to the sporadic frosty nights or short periods of frost occurring in northern Fennoscandia after the end of August. 


\section{Discussion}

With its large size, thick, hard context, yellow and clearly zonate pileus and long-inrolled short-haired pileus margin, Lactarius scrobiculatus differs clearly from the other yellow species treated here. Microscopically, the scantiness and small size of the marcocystidia and the unreticulated spores differentiate it fairly well from the other species. The white tomentum at the top of the stipe, continuing between the decurrent, mainly unforked lamellae, and the scrobiculate stipe, distinguish it from all the other yellow species except L. leonis; the latter, however, has a woolly pileus margin and very large macrocystidia.

Being large and gregarious, L. scrobiculatus is a conspicuous fungus in nature. As it is fairly common in South Sweden and the mountains of Central Europe, it is one of the most cited Lactarius species in the literature. The other yellow species treated here are absent or rare at those latitudes, and the European reports of $L$. scrobiculatus evidently mostly refer to $L$. scrobiculatus s. str. or to taxa more closely related to it than to the other, mainly boreal, yellow species treated here.

In North America Hesler \& Smith (1960) recognized two varieties: $L$. scrobiculatus var. scrobiculatus and L. scrobiculatus var. pubescens A.H. Smith. The latter is a pale yellow fungus with small, narrowly ellipsoid (6.6.-8.6. $\times$ 4.8.-5.7. $\mu \mathrm{m}$ ) spores, whose ornamentation is weak, low and nearly reticulate. Judged by the original material, it is clearly a disticnt species, not closely related to $L$. scrobiculatus s.str. or to the other American L. scrobiculatus varieties.

L. scrobiculatus 'var. scrobiculatus' sensu Hesler \& Smith (1960) is pale yellow to buff with the edge 'shaggy tomentose to coarse fibrillose', the hairs later forming low radial ridges (as in L. tuomikoskii, Figs. 7 $\mathrm{d}, \mathrm{e})$. The stipe is somewhat scrobiculate, especially in the lower part. The spores are 7.7.-9.1 $\times 6.3-7 \mu \mathrm{m}$ in size, nearly subglobose, with nodulose irregular ridges and isolated warts up to $1.5 \mu \mathrm{m}$ high. The macrocystidia are long $80-130 \times 8-11 \mu \mathrm{m}$, projecting $40-80 \mu \mathrm{m}$. This taxon seems to be another distinct species not closely related to L. scrobiculatus s.str., but nearer to L. tuomikoskii. In their later monograph, Hesler \& Smith (1979) united their former 'var. scrobiculatus' with L. payettensis A.H. Smith var. canadensis A.H. Smith under the name L. scrobiculatus var. canadensis (A.H. Smith) Hesler \& A.H. Smith. However, the two taxa are not identical, $L$. payettensis var. canadensis being closer to L. olivinus (see below) than to L. scrobiculatus 'var. scrobiculatus' sensu Hesler \& A.H. Smith (1960) or to L. scrobiculatus s.str.

L. scrobiculatus var. canadensis sensu Hesler \& A.H. Smith (1979) also seems to include a third taxon, most closely related to L. leonis (Smith 24494 in MICH examined).

L. scrobiculatus s.str. is evidently absent from North America. The closest taxon there seems to be L. alnicola A.H. Smith (Hesler \& Smith 1960), which has a thick hard context, 'only short-tomentose pileus margin,... instantly acutely acrid taste', similar spore ornamentation and small, scanty macrocysticia. The chief features separating if from $L$. scrobiculatus are the latex, which is stated to be scanty and to stain the wounds yellow, though not turning yellow itself. The pileus colour seems to be paler than in L. scrobiculatus.

L. alnicola var, pungens Hesler \& A.H. Smith (1979) appears fairly similar to L. scrobiculatus s.str. (especially the young basidiocarp in the type specimen of var. pungens), but seems to have a thin and fragile context rather than a thick and hard one, somewhat larger and more roughly ornamented spores and according to Hesler \& Smith (1979), a pungent smell and constant latex colour.

A further taxon, probably better placed in the subsection Piperites, is L. alnicola var. pitkinensis Hesler \& A.H. Smith (1979), with an ochraceous, thin infundibuliform pileus, short white stipe, large and very roughly ornamented spores, abundant, short, but relatively wide macrocystidia and unchanging latex colour.

\section{Specimens examined}

Denmark. Sjaelland: 1973 Mykologisk Feltkursus (C).

Norway. Ostfold: 1956 Ramm (O). Akershus: 1962 Eckblad (O), 1962, 1963 Egelund \& Gulden (O), 1967 Guttormsen (O), 1956 Stordal (O), 1967 Sunding (O), 1941 Sörlye (O). Oppland: 1950 Fosheim (O), Stordal 15558, 15736, 15874, 17363, 17431 (O). Telemark: Torkelsen 359/777 (O). Buskerud: Gulden 218/66, 384/67 (O), Stordal 10773 (O). Hordaland: 1977 Nergaerd \& al. (O). Sör-Tröndelag: 1951 Gjaerevoll (TRD), 1934 Höeg (2 ex. TRD), 1938 Hoffstad (TRD), Stordal 6612 (O, TRD), 1951 Stordal et al. (TRD). NordTröndelag: Ky 9256, 80460 (H), 1951 Olsson (TRD), 1971 Sivertsen (TRD), Stordal 6333, 12437, 13378, 13414, 14387, 14393 (TRD). Nordland: 1974 Vefsna-prosjektet (TRD).

Sweden. Gotland: 1946 Fries (UPS). Västergötland: 1965, 1966 Andersson (GB), Karlvall 10468, 10616, 12771 (GB), Ky $82607(\mathrm{H}), 1965$ Strid (GB). Östergötland: Ky 82680, 82691 (H). Värmland: 1957 Andersson (GB), Ky 7916, 82569, 82575 (H). Närke: 1972 Ryman (UPS). Södermanland: 1945 Dahlgren (UPS), 1951 Haglund (S), 1946 Rundquist (S), 1945 Suber (S). Stockholm: 1888, 1893, 1895 Romell (S). Uppland: 1949 Berggren (S), 1946, 1950 Haglund (S), 1949 Haglund et al. (S), 1946 Ingelström (S), $1887 \mathrm{Ku}-$ gelberg (S), Ky 5125, 79626 (H), 1945 Lundell (S), 1951 Lundell (UPS), 1971, 1974 Nannfeldt (UPS), 1946 Rundquist (S), 1948 (2 ex.), 1952 Rydberg (S), 1950 Rydberg \& Haglund (S), 1946 Zander (S). Västmanland: 1956 Lundell \& Nilsson (UPS). Dalarna: Ky 79523, 79538, 79547, 79548, $79584,80522,82540,83546(\mathrm{H})$. Gästrikland: 1972 Nannfeldt (C, UPS), Strid 15733 (S). Medelpad: Korhonen 5420, 5444, 5446a (H), Ky $82529(\mathrm{H}), 1977$ Lindström (UPS). Angermanland: Ky 5042, 79234, 79319, 80405, 81632, 83499 (H). Härjedalen: Ky 80488, $81465(\mathrm{H})$. Jämtland: Ky 8418 , $9261,79364,79389,79405,79438,79441,79457,80414$, $80446,80466,81481,81501,81505,81513,81616(\mathrm{H})$. Asele Lappmark: Ky 80380, $80399(\mathrm{H})$. Lycksele Lappmark: Ky 80336, 81575 (H). Lule Lappmark: Ky 80246.

Finland. Ahvenanmaa: 1981 Alho \& Laine (TUR), 1973, 1974 Haeggström (H), 1963 Kankainen (TUR), Korhonen 2052, 2531, $3999(\mathrm{H}), 1977$ Korhonen \& Tuomikoski $(\mathrm{H})$, 1978 Mäkinen (3 ex. TUR), 1978 Pohjola (OULU), Skytén 1396, $1406(\mathrm{H})$. Varsinais-Suomi: 1972, 1979 (2 ex.) Alho (TUR), 1960, 1962 Kallio (TUR), Ky 9572, 9475, 9651, 9657, $801158,801212,801232,801254,801280,801301.801313$, $801344,801374,801406,801431,801462,801478,811376$, $811707,811722,811737(\mathrm{H}), 1967$ Pohjola (TUR), Uotila $31809(\mathrm{H})$. Uusimaa: Askola $160(\mathrm{H}), 1937$ Frey $(\mathrm{H}), 1982$ Härkönen (H), 1980 Issakainen (H), Ky 9562, 79884, $811304,811615,811677,811691(\mathrm{H}), 1943$ Nyberg $(\mathrm{H}), 1951$ Tuomikoski (2 ex. H). Satakunta: 1972 Alho (TUR), Ky 
82752, $83036(\mathrm{H}), 1957$ Ståltin (H). Etelä-Häme: Ky 81710 , $81739,81757,811571$ (H). Etelä-Savo: Ky 811469,811540 (H). Etelä-Pohjanmaa: Alanko 15942 (H), Ky 83057 (H). Pohjois-Savo: Heikkilä 512, 554, 547, 676 (KUO), Ky 80781 , $80891,80904,82176,83178,83234(\mathrm{H})$, Vauras Sa-13, (KUO). Pohjois-Karjala: Ky 80743, 80767,80959 (H). KeskiPohjanmaa: Ky 81803, 82414 (H). Kainuu: Ky 80565, 80634, 81844, 81866, 81888, 81948, 83297, 83314, $83348(\mathrm{H}), 1967$ Ohenoja (OULU), 1976 Tuomikoski (H). Perä-Pohjanmaa: Ky 4898, 4934, 81964, 81989, 811002, 83436, $83450(\mathrm{H})$, 1981 Ohenoja (OULU), 1979 Tammilehto (OULU), 1974 Tuomikoski (H), 1972 Ulvinen (OULU). Koillismaa: 1967 Korhonen 4092, 4104, 5487, 5500 (H), Ky 811075, 811112 , $811164,811181,811182,811208,811215,811230,83392(\mathrm{H})$, 1974 Pohjola (OULU), 1974 Tuomikoski (2 ex. H), 1964 Ulvinen (OULU), 1966 Viramo (OULU).

U.S.S.R. Estonian S.S.R.: 1981 Vaasma (TAA).

2. Lactarius leonis Kytövuori, spec. nova

Illustrations. Korhonen (1984)

Pileus 6-16 (-20) cm latus, convexo-depressus, dein planoconvexus, margine laxo involuto, aequaliter lanato, dein recto, saepe leviter undulato, glabro; gelantinosus, ochraceus vel pallide luteus, obscure zonatus, margine pallido. Latex albus, ad aeris contactum mox saturate sulphureus, in $\mathrm{KOH}$ aurantiacus. Sapor acer. Lamellae rectae, prope stipitem rarrissime furcatae. Stipes $4-8 \mathrm{~cm}$ longus, $1.5-3 \mathrm{~cm}$ crassus, cavus, siccus, pallidus vel pileo concolorus, scrobiculatus. Sporae 6.8$9.1 \times 5.9-7.3 \mu \mathrm{m}$, subglobosae, ornamento amyloideo tenui (sub)reticulato. Macrocystidia dispersa 45-130 $\times 6-13 \mu \mathrm{m}$, subulata, 50-100 $\mu \mathrm{m}$ projecta. In Fennoscandia calciphilus, in silvis ugliginosis, cum Picea abiete. Augustio et Septembri.

Holotypus: Sweden, Ångermanland, Fjällsjö, S end of the lake Tásjön, by the brook from Stortjärn, S of the road, narrow, rather open, alluvial spruce-hardwood swamp with Picea abies, Betula pubesencs and Salix spp., 260 m, abundant with Lactarius scrobiculatus and L. olivinus, 19.VIII. 1981 P. \& I. Kytövuori 81634 ( $\mathrm{H}$, isotypi in $\mathrm{MICH}, \mathrm{K}, \mathrm{O}$, PRM, UPS, Z).

Pileus 6-16 (-20) cm wide, when young with centre slightly depressed, the margin gently inrolled, with age becoming broadly convex to plano-convex with centre slightly depressed, edge often wavy. When moist pileus covered with thick gelatinous layer formed by the ixocutis and swollen hairs (especially in the marginal part). Young edge evenly woolly bearded, the curled hairs clearly longer than the hairs of $L$. scrobiculatus. Outrolled margin of mature pileus (nearly) glabrous, the gelatinous curly hairs appressed on the marginal surface.

Colour yellowish white, pale yellow, corn yellow, amber yellow to pastel yellow. The marginal part of the outrolled pileus whitish, the centre stronger yellow with brownish tint, very obscurely zonate with darker, brownish zigzag zones (soaked pileus sometimes with very narrow obscure watery zones); young pileus darker, as the whitish edge is inrolled. Context rather thin (especially in the marginal part), fragile, not hard. Latex scanty, white, rapidly turning sulphur yellow when exposed, orange in $\mathrm{KOH}$, acrid or becoming acrid.

Lamellae close, narrow, straight, not or seldom forked near stipe, adnate, whitish or with weak salmon tint, somewhant spotted, lamellulae numerous.

Stipe relatively slender, $4-8 \mathrm{~cm}$ long, $1.5-3 \mathrm{~cm}$ thick, of even thickness or thickening somewhat downwards, scrobiculate up to top with unequal, not depressed, olive yellow spots on whitish, pruinose surface, dry at surface. The coarse hairs absent from the base, the white colour not stretching up between the lamellae.

Spores $6.8-9.1 \times 5.9-7.3 \mu \mathrm{m}$, length/width ratio $1.10-1.30$, subglobose, with thin amyloid ornamentation (not exceeding $0.5 \mu \mathrm{m}$ in height) forming a reticulum, plage small.

Basidia 33-45 × 7-10 $\mu \mathrm{m}, 4$-spored. Macrocystidia scattered, but denser than in L. tuomikoskii, somewhat concentrated between the gills, $45-130 \times$ $6-13 \mu \mathrm{m}$, projecting $30-100 \mu \mathrm{m}$, with the broadest point outside the hymenium. Pseudocystidia $5-8 \mu \mathrm{m}$ thick

In Fennoscandia calciphilous, growing in and beside rich, moist, often swampy depressions in spruce forests. Scattered or in groups of a few fruit bodies. Only with Picea abies. Boreal, rather rare. August to September.

\section{Distribution and ecology}

Though L. leonis is a calciphilous species in Fennoscandia, it is less exacting than L. scrobiculatus. In Finland it is known in areas with mesotrophic or eutrophic forests, especially in the northern part of the country, but is nowhere very common and is scattered in its habitats. In Central Finland it seems to be rare, but not entirely restricted to the most fertile places like L. scrobiculatus. In South Finland it may be rarer than L. scrobiculatus. However, Fig. 4 does not give a true picture of the distribution, as most of my excursions in southern Finland were made too late in autumn for this species.

In Scandinavia L. leonis is fairly common in spruce forests on the eastern side of the Scandes, especially on Caledonian and Cambro-Silurian bedrock. Eastwards, on crystalline Precambrian bedrock, the species is rarer and occurs locally in richer habitats, especially along rivers. On the western side of the Scandes it is known in only two places, but is probably commoner. L. leonis is poorly collected by mycologists and none of my own excursions in Norway were made in a good mushroom season.

Towards the south L. leonis is rare, but is possibly found in South Sweden. One specimen from the island Saaremaa in Estonia (TAA) was examined. From Central Europe I have seen two specimens collected by Bresadola (in S) on the southern side of the Alps.

L. leonis seems to grow only with Picea abies. In suitable edaphic conditions it is found up to the uppermost spruce woods. It grows in sloping, moist, swampy depressions in spruce and spruce-birch forests, in thickets around seepages, and in and by narrow, swampy, alluvial woods along rivers and brooks. It hardly ever grows on unpaludified upland soil. In suitable places it is often associated with $L$. scrobiculatus and L. tuomikoskii.

L. leonis is a boreal species centred in the northern boreal and upper oroboreal zones. Besides the direct effect of the climate, another cause of the northern tendency is that sloping, relatively virgin sprucehardwood swamps are much commoner at higher latitudes and altitudes in Fennoscandia. The species will probably dissappear when those habitats have been 

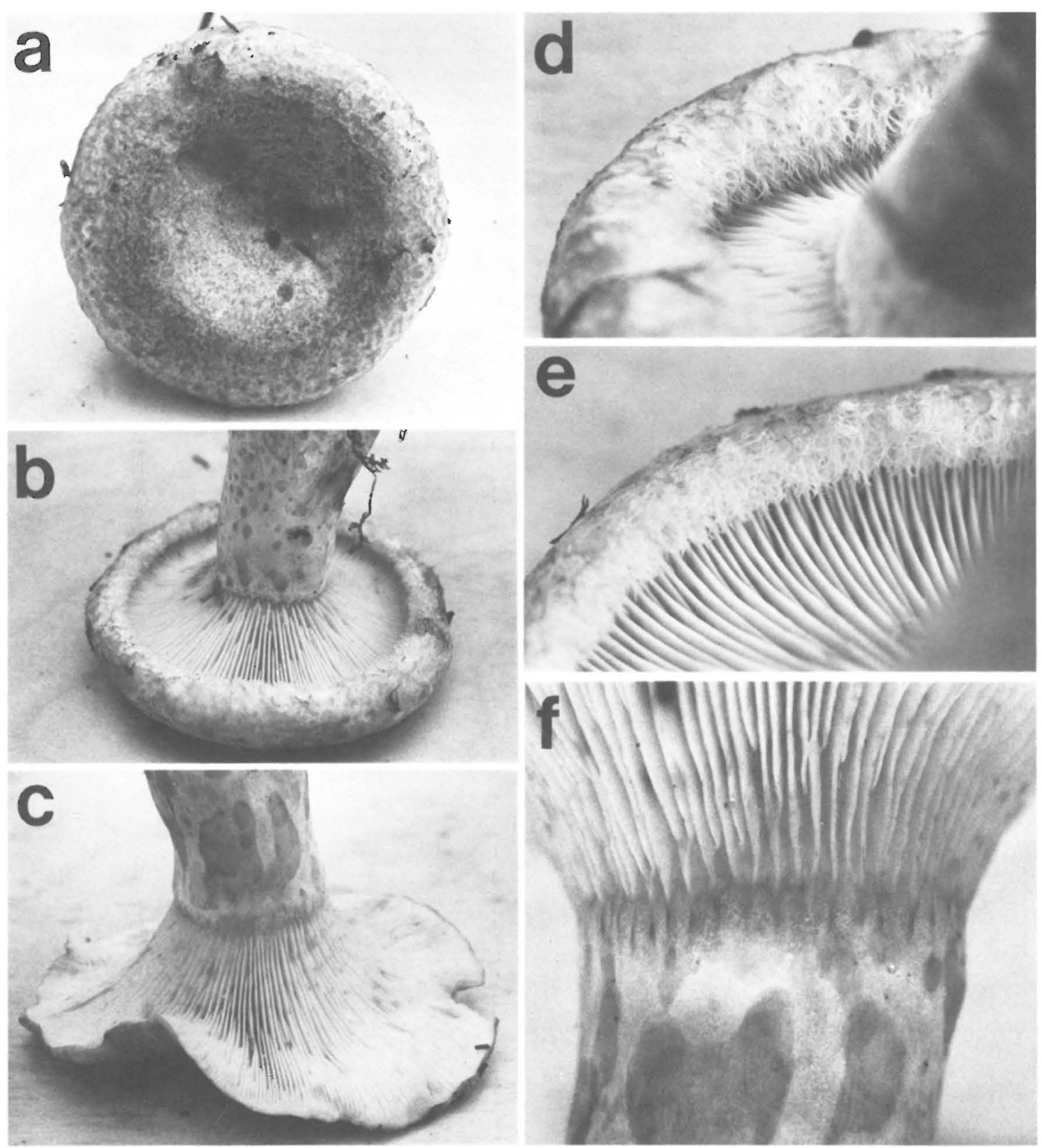

Fig. 3. Lactarius leonis. - a, b, e) Ky 81586. - c, f) Ky 81786. - d) Ky 81545.

dried out by draining or clear-cutting. Draining for forestry purposes has restricted its possibilities in the middle and southern boreal zones in Fennoscandia.

\section{Phenology}

The fruiting season of $L$. leonis is short, lasting from late July to mid-September (Fig. 17) and ending with the first low temperatures, as the species is sensitive to even short frosts. Even when late autumn is warm, its capacity to form new basidiocarps is much smaller than in L. scrobiculatus.

\section{Discussion}

L. leonis is intermediate between L. scrobiculatus and L. tuomikoskii. From the former it is distinguished by its softer context, paler colours, the whitish surface of the outrolled pileus margin, and even woolly hairs on the pileus edge and narrow lamellae with a white or 


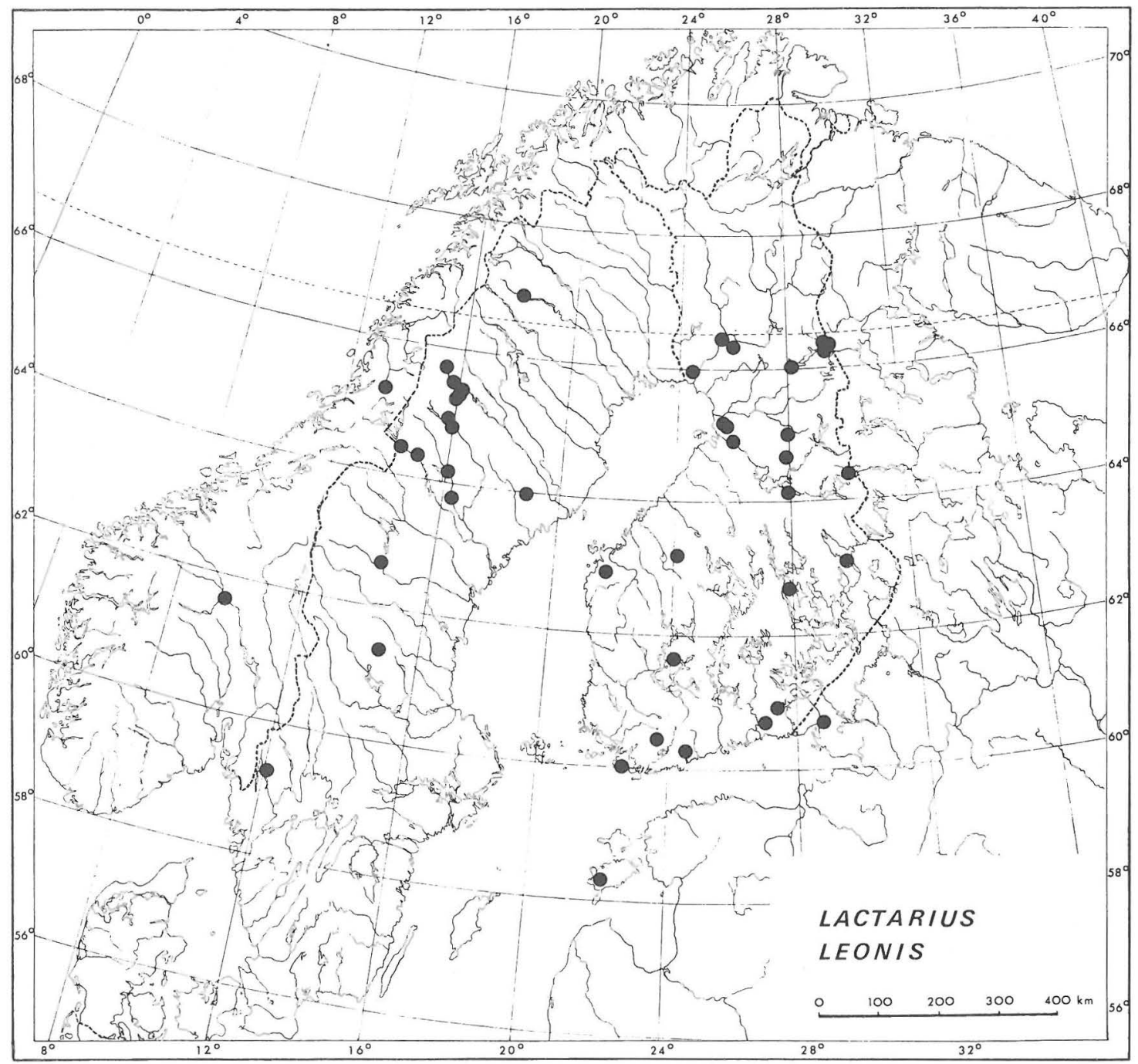

Fig. 4. Distribution of Lactarius leonis in NW Europe according to the material examined.

slightly pinkish tint. It lacks the white tomentum between the lamellae at the top of the stipe. From $L$. tuomikoskii it differs in the obscurely zonate and marginally whitish pileus, narrow straight lamellae and the spotting extending to the top of the stipe. Microscopically, L. leonis is identified by its small, subglobose spores with weak, \pm reticulate ornamentation, and large macroscystidia.

The specimen Smith 74733 from Michigan (MICH) under the name $L$. scrobiculatus var. canadensis (det. A.H. Smith, cited in Hesler \& Smith 1979) with its short and weakly spotted stipe, coarsely woolly pileus margin, crowded, narrow lamellae and subglobose, finely ornamented spores, seems to be similar to $L$. leonis, but its definite identification needs more American material. It does not belong to the same taxon as the holotype of L. scrobiculatus var. canadensis (A.H. Smith) Hesler \& Smith.

\section{Specimens examined}

Norway. Oppland: Ky 10313 (H). Norland: Ky 81545 (H).

Sweden. Värmland: Ky 81337 (H). Dalarna: Ky 79476, 80523 (H). Angermanland: Korhonen 5456 (H), Ky 79298, 81634-81636, 81649 (H). Jämtland: Ky 80439, 81498, 81606 (H). Asele Lappmark: Ky 79198, 80400, 81586, $81594(\mathrm{H})$. Lycksele Lappmark: Ky 6399, 80359, 81579 (H). Lule Lappmark: Ky 80247.

Finland. Varsinais-Suomi: Ky 811346, $811377,83020(\mathrm{H})$. Uusimaa: 1981 Korhonen (H). Etelä-Karjala: 1952 Kujala (H). Etelä-Häme: Ky 81745, 81746 (H). Etelä-Savo: Ky 66001 (H). Etelä-Pohjanmaa: 1979 Heikkilä (OULU). Pohjois-Savo: Ky $80782(\mathrm{H})$, Vauras $1472 \mathrm{~F}(\mathrm{H})$. Pohjois-Karjala: Korhonen 2008, 5521 (H). Keski-Pohjanmaa: Ky $81786(\mathrm{H})$. Kainuu: Ky 80566, 81910, 81931, 81949, $811248(\mathrm{H})$. Oulun Pohjanmaa: Ky 81833 (H), 1981 Ohenoja (OULU), 1966, 1974 (2 ex.), 1981 Ulvinen (OULU). Perä-Pohjanmaa: Ky 5392, 81973, 81975, 811003 (H). Koillismaa: Ky 811101, $811166,811203(\mathrm{H}), 1951$ Tuomikoski $(\mathrm{H}), 1979$ Ulvinen (2 ex. OULU). 
U.S.S.R. Karelian A.S.S.R.: 1892 Thesleff (H). Estonian S.S.R.: 1979 Vaasma (TAA).

\section{Lactarius olivinus Kytövuori, spec. nova}

Illustrations. Korhonen (1984).

Pileus $5-13 \mathrm{~cm}$ latus, convexo-depressus vel plano-depressus, margine tomentoso, mox recto et glabro; cute pilei marginali squamis agglutinatis pellita; viscidus, pallide olivaceostramineus, dein olivaceus. Latex albus, ad aeris contactum mox saturate sulphureus, in KOH aurantiacus. Sapor acer. Lamellae prope stipitem furcatae, flexuosae. Stipes 3-8 cm longus, $1-3 \mathrm{~cm}$ crassus, cavus, siccus, pileo concolorus, variegatus, non scrobiculatus. Sporae 8.2-10 (-10.9) X 6.1-7.3 $\mu \mathrm{m}$, late ellipsoideae, ornamento amyloideo non reticulato. Macrocystidia abundantia, 45-90 × 10-14 $\mathrm{mm}$, fusoidea vel lanceolata, 30-70 $\mu \mathrm{m}$ projecta. In Fennoscandia claciphilus, in silvis uliginosis, cum Picea abiete. Augustio et Septembri.

Holotypus: Sweden, Åsele Lappmark, Vilhelmina, Dikanäs, E end of the lake Diktsjön, ca. $100 \mathrm{~m}$ from the bridge, alluvial spruce-hardwood swamp with Picea abies, Betula pubescens, Juniperus communis, Salix glauca, S. lapponum, S. phylicifolia, Calamagrostis chalybaea, Deschampsia cespitosa etc., on and between hummocks, $435 \mathrm{~m}, 16$. VIII.1981 P. \& I. Kytövuori 81587 (H, isotypi in MICH, K, O, PRM, UPS, Z).

Pileus 5-13 cm wide, broadly convex-depressed to plano-depressed edge incurved only when quite young, soon bent to outrolled, the centre slightly depressed. Viscid or thinly slimy, soon dryish. Young margin evenly woolly-tomentose (or minutely bearded), tomentum often forming a continuous rim covering the outer ends of the lamellae. Outrolled margin glabrous, marginal surface with thin, agglutinated scales, marginal cuticle often radially chapped. Colour milk white to pale yellow with dull greenish tint, the centre greyish yellow, linden yellow to olive yellow, the thin agglutinated marginal scales, especially in dryish condition, dark olive yellow; azonate or with some obscure, darker zones. Context rather thin, fragile, softish. Latex scanty, white, rapidly turning sulphur yellow when exposed, orange in $\mathrm{KOH}$, acrid or becoming acrid.

Lamellae white, somewhat forked and flexuose near the stipe, broarder and farther apart than in $L$. leonis, lamellulae numerous.

Stipe $3-8 \mathrm{~cm}$ long, $1-3 \mathrm{~cm}$ thick, of even thickness, of ten somewhat curved at the base, concolorous with the pileus, usually not scrobiculate, but slightly varietaged, often with narrow, whitish ring at the top, hollow, dry at surface.

Spores 8.2-10 (-10.9) × 6.1-7.3 (-7.9) $\mu \mathrm{m}$, lenght/width ratio $1.23-1.40$, broadly ellipsoid with amyloid ornamentation formed by long ridges, shorter fragments and isolated warts, not forming a reticulum, prominences up to $1 \mu \mathrm{m}$ high. Plage distinct. The ornamentation like that of $L$. scrobiculatus but the ridges somewhat broader.

Basidia 37-47 $\times 8-12 \mu \mathrm{m}, 4$-spored. Macrocystidia abundant, $45-90 \times 10-14 \mu \mathrm{m}$, fusoid to lanceolate, projecting $30-70 \mu \mathrm{m}$, with the broadest point usually outside the hymenium. Pseudocystidia 4-7 $\mu \mathrm{m}$ thick.

In Fennoscandia calciphilous, most typically occurring along brooks and rivers in alluvial spruce-willow-birch thickets. Also in spring-fed spruce swamp depressions. In groups, often gregarious. Only with
Picea abies. Mainly boreal, rather rare. August to September.

\section{Distribution and ecology}

In Fennoscandia L. olivinus is a calciphilous species, occurring in rich sites but being less exacting than $L$. scrobiculatus. In Finland it seems to be lacking in some central parts, and is nowhere common. The distribution shows less concentration in the north than that of $L$. leonis. In the south it was found less often than L. scrobiculatus, but my South Finnish excursions have mostly been too late for this species.

In Scandinavia the distribution of $L$. olivinus resembles that of $L$. leonis, but it seems to be commoner in the south. Most of the Scandinavian localities of $L$. olivinus in Fig. 6 were revealed by blind collections, as all my Scandinavian excursions, in good or moderate mushroom seasons, took place before I was aware of the existence of the species. This suggests that the species may be commoner than is evindent from Fig. 6. A special search of alluvial riverside thickets may considerably expand its known range towards the Gulf of Bothnia in the areas of Precambrian bedrock. Outside Fennoscandia the species is known in Estonia.

L. olivinus seems to grow with Picea abies only, characteristically occurring along brooks and rivers in alluvial, spruce-dominated thickets. Sometimes the spruce trees are scattered or solitary, Betula and various Salix species being the main components. Often a continuous moss cover is lacking or is thin, various broad-leaved herbs being abundant. In such habitats L. olivinus grows on high hummocks, especially on their sides. After dryish summers it also grows on bare peat between the hummocks (in normal summers such a surface is covered by water). It may grow along small brooks, on stones or rocks with a soil and moss layer sometimes thinner than $1 \mathrm{~cm}$.

In addition, L. olivinus grows in moist spring-fed swampy depressions in rich spruce forests (cf. below), but is rare in such habitats and restricted to the most fertile regions. On true upland soil it does not thrive at all.

L. olivinus appears to be a boreal species, which is not as concentrated to the northern part of the zone as L. leonis. Rare occurrences are also known in the northern part of the hemiboreal zone.

Phenology

The fruiting period of $L$. olivinus is rather short. In Fennoscandia the first basidiocarps are found at the end of July, and growth ceases in mid-September (Fig. 17), depending largely on the local climate, as the species is sensitive to frosty nights. Basidiocarps of all ages exist in rich colonies, where new ones are produced continuously. However, even in warm autumns the production stops much earlier than in $L$. scrobiculatus.

\section{Discussion}

L. olivinus may resemble small L. leonis or L. tuomikoskii, but is differentiated by the greenish tint and the agglutinated scales of the pileus. The stipe is concolorous with the pileus, slightly variegated, but not 

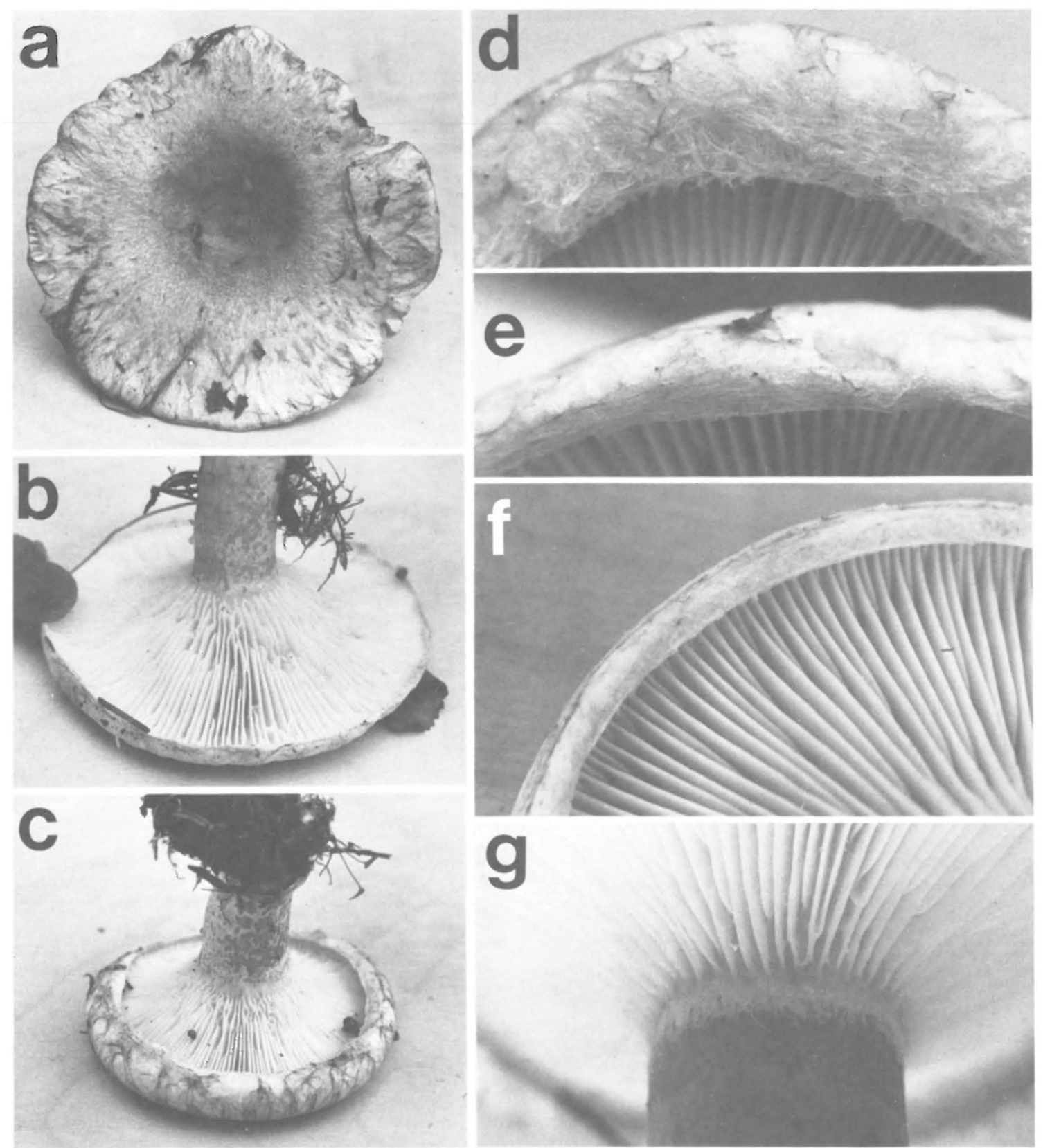

Fig. 5. Lactarius olivinus. - a, c) Ky 81587 (type). - b) Ky 81580. — d, e, g) Ky 81890. — f) Ky 81617. — d) Very young basidiocarp.

spotted as in L. leonis or whitish as in L. tuomikoskii. In the forking and flexing of the lamellae near the stipe it resembles $L$. tuomikoskii. A characteristic, though not constant, feature of L. olivinus is the white ring at the top of the stipe.

Microscopically, L. olivinus is recognized by its crowded macrocystidia, which are broader than in any other species treated here (can be examined under a dissecting microscope in dried specimens without any preparation), and by the spore ornamentation, which closely resembles that of $L$. scrobiculatus, a species practically without macrocystidia. In very old or water-soaked basidiocarps or in specimens dried in excessive heat, the macrocystidia have usually collapsed and care is needed in the determination of such specimens. 


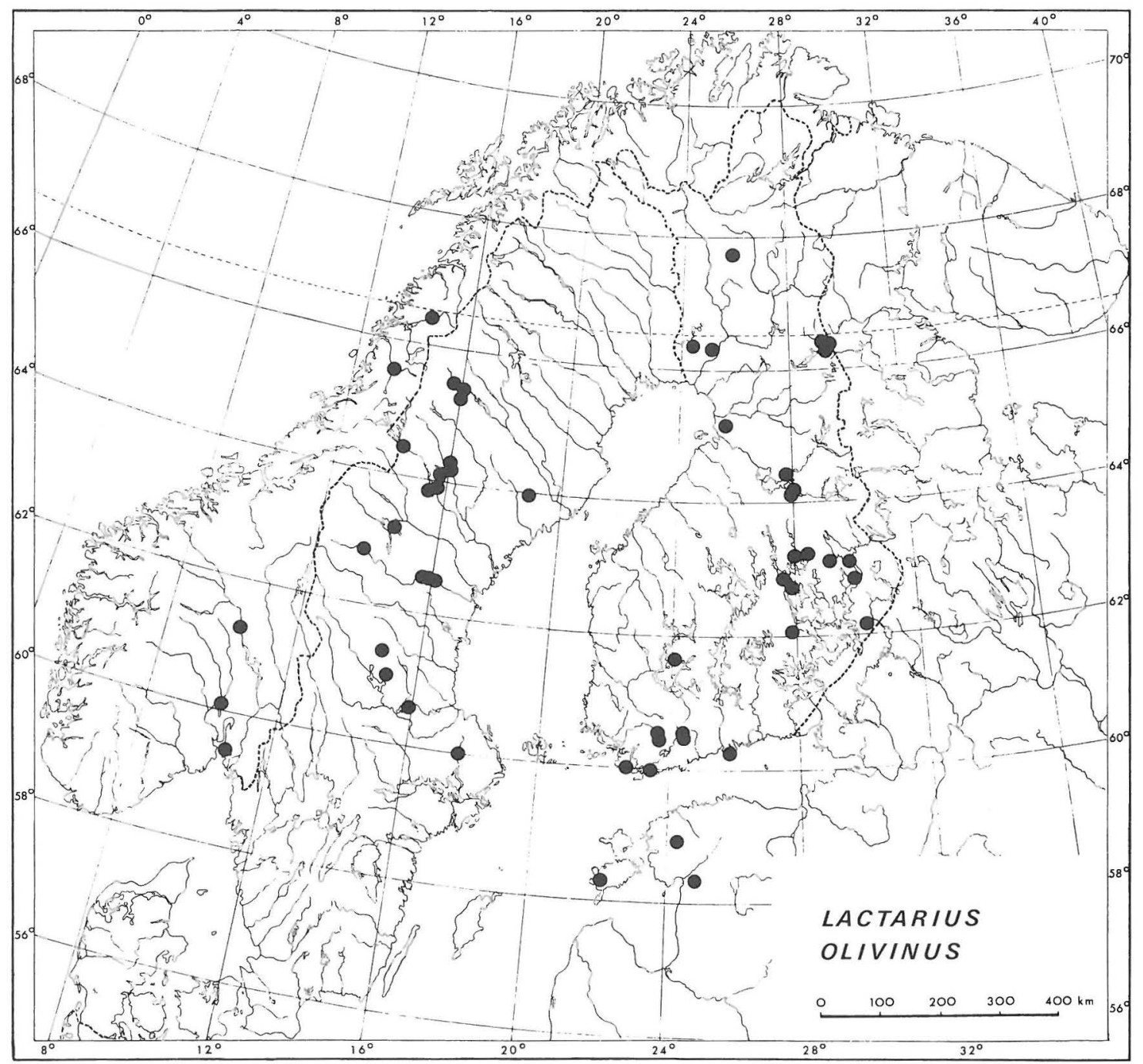

Fig. 6. Distribution of Lactarius olivinus in NW Europe according to the material examined.

The greenish tint seems to be constant in L. olivinus colonies along brooks and rivers, but in spring-fed, swampy depressions in rich, moist spruce forest the colonies may have brighter yellow colours with little or no greenish tint (e.g. Ky $81617,81890 \mathrm{H}$ ). As no other distinguishing characters were found, the colour form was not recognized taxonomically, but in nature it may be confusing and should be kept in mind.

L. olivinus seems to be closely related to the American $L$. payettensis var. canadensis A.H. Smith. That fungus is small $(4-6 \mathrm{~cm})$, pileus 'pale olive buff,... viscid, soon dry, ... latex scanty, turning yellow, ... cuticle often broken into appressed squamules', 'stipe concolorous with the cap and often scrobiculate', macrocystidia $9-13 \mu \mathrm{m}$ borad, subclavate to fusoid. In the type specimen the spores are smaller $(7.7-8.4$ $\times 6.1-6.6 . \mu \mathrm{m})$ than in L. olivinus and the ornamentation is more labyrinthine. The macrocystidia are relatively broad, ventricose-rostate, but smaller (55$70 \mu \mathrm{m}$ long) than in L. olivinus, with the broadest point in the hymenium and projecting only $10-25$ $\mu \mathrm{m}$. Thought close, L. payettensis var. canadensis and L. olivinus seem to be different species.

L. payettensis A.H. Smith var. payettensis also has features in common with $L$. olivinus: the 'pale olivebuff colour', agglutinated-hairy margin, hairs becoming fuscous with age, broad macrocystidia and spore ornamentation. However, it is differentiated from L. olivinus by the thick and robust external appearance, short, thick, white, unpolished stipe and the latex, which does not turn yellow. L. olivinus, $L$. payettensis var. payettensis and L. p. var. canadensis evidently form a natural species aggregate. 


\section{Specimens examined}

Norway. Östfold: 1956 Ramm (0). Oppland: Ky 72001 (H). Buskerud: Gulden 236/66 (0). Nordland: Ky 73001, 81566 (H).

Sweden. Uppland: 1921 Lundell (S). Dalarna: Ky 79478, 79550, $79585(\mathrm{H})$. Medelpad: Korhonen 5419, 5424, 5443, 5447, 5451, 5453 (H), Muskos 292, 1335. Angermanland: Ky 79320, 81633, 81650 (H). Jämtland: Ky 9262, 79390, 79442 $80436,81482,81607,81617(\mathrm{H})$. Asele Lappmark: Ky 81587 (H). Lycksele Lapmark: Ky 80338, 80360, $81580(\mathrm{H})$.

Finland. Varsinais-Suomi: Ky 79855, 811378, 83017 83021, 83607 (H). Uusimaa: 1925 Nyberg (H), 1957 Schulmann (H). Etelä-Häme: Ky 81740-81744, 81747 (H), Mäkinen 81-585 (TUR). Pohjois-Savo: Korhonen 5541 (H), Ky 80783, $83182(\mathrm{H})$, Vauras 733F (KUO), 1503F (H), Pohjois-Karjala: Ky 80744, 80768, 80871, 80960 (H), 1956 Tuomikoski (H). Kainuu: Korhonen 1558 (H), Ky 80566, 81890-81892 (H). Oulun Pohjanmaa: 1966 Ulvinen (OULU). Perä-Pohjanmaa: Ky 83451 (H), 1957 Tuomikoski (2 ex. H). Koillismaa: Korhonen 4799, 5518 (H), Ky 2362, 811102 , $811167,811209,811217(\mathrm{H}), 1974$ Tuomikoski $(\mathrm{H})$. Kittilän Lappi: Ky 6887 (H).

U.S.S.R. Estonian S.S.R.: 1964, 1966 Kalamees (TAA), 1966 Lasting (TAA).

\section{Lactarius tuomikoskii Kytövuori, spec. nova Illustrations. Korhonen (1984).}

Pileus 7-14 (-18) cm latus, convexo-depressus, dein planodepressus, margine involuto, strigoso, dein recto et glabro, cute pilei marginali tenuiter porcata; glutinosus, pallide luteus, azonatus. Latex albus, ad aeris contactum mox saturate sulphureus, in $\mathrm{KOH}$ aurantiacus. Sapor acer. Lamellae albae, prope stipitem aliquantum furcatae et fleuxuosae. Stipes 4-8 $(-11) \mathrm{cm}$ longus, $1.3-3 \mathrm{~cm}$ crassus, cavus, siccus, pileo concolorus vel pruinosus, non scrobiculatus. Sporae 7.7-10.2 (-10.9) $\times 6.3-7.7 \mu \mathrm{m}$, late ellipsoideae, ornamento amyloideo subreticulato. Macrocystidia dispersa, 40-100 × 5-8 um, aculeata vel subulata, 15-70 $\mathrm{mm}$ projecta. In Fennoscandia non calciphilus, in silvis humidis, cum Picea abiete. Augustio et Septembri.

Holotypus: Finland, Perä-Pohjanmaa, Rovaniemi rural commune, Pisavaara, grove-like spruce forest, 29. VIII.1974 R. Tuomikoski $(\mathrm{H})$.

Etymology: Named in honour of Prof. Risto Tuomikoski, a distinguished student of Finnish Lactarius species (cf. Karstenia 21(1), frontispiece).

Pileus $7-14(-18) \mathrm{cm}$ wide, convex-depressed with margin broadly incurved when young, with age becoming plano-depressed with nearly outrolled margin, slimy. Young margin coarsely bearded; marginal surface later with appressed radial ridges formed by pursed hairs, the marginal cuticle sometimes radially chapped between the ridges. Colour yellowish white, pale yellow, butter yellow to maize yellow throughout, without greenish tint, azonate, the centre concolorous with the margin or only slightly darker. Context fairly thick, fragile, fairly soft. Latex scanty, white, rapidly turning sulphur yellow when exposed, orange in $\mathrm{KOH}$, acrid.

Lamellae pure white, fairly broad, close, many of them forked near the stipe, flexuose near the stipe. Lamellulae fairly numerous.

Stipe 4-8 (-11) cm long, 1.3-3 cm thick, of even thickness or tapering downwards, with wide central cavity, whitish pruinose, latex concolorous with the pileus, dry, fairly soft, without distinct ring or white tomentum at top, not scrobiculate or with a few large spots at the base.
Spores $7.7-10.2(-10.9) \times 6.3-7.7 \mu \mathrm{m}$, lenght/ width ratio $1.24-1.42$, broadly ellipsoid, with amyloid ornamentation of stretched warts (or short ridges) connected by fine lines, forming an incomplete, broken reticulum, prominences up to $1 \mu \mathrm{m}$ high, plage rather small.

Basidia 39-50 ×9-12 $\mu \mathrm{m}, 4$-spored. Macrocystidia scattered, somewhat concentrated between the gills, $40-100 \times 5-8 \mu \mathrm{m}$, aculeate to subulate, with the broadest point in or outside the hymenium, projecting $15-70 \mu \mathrm{m}$ over the hymenium. Pseudocystidia $6-10 \mu \mathrm{m}$ thick.

In Fennoscandia not calciphilous, but favouring more fertile soils. Most often on Sphagnum girgensohnii or Hylocomium spendens in spruce-dominated upland or slightly paludified forests. Solitary or in small groups. Only with Picea abies. Boreal, fairly common, August to September.

\section{Distribution and ecology}

L. tuomikoskii is not calciphilous in Fennoscandia, but avoids the least fertile regions. In Finland it grows throughout the country, but favours the richer forest sites. It is not common and the basidiocarps are always scattered, occurring singly or in small groups.

In Scandinavia L. tuomikoskii is commoner than in Finland and most frequent in the regions of Caledonian and Cambro-Silurian bedrock. It is also fairly abundant west of the Scandes. Eastwards its range reaches the Gulf of Bothnia and it is the only species in the yellow group occurring fairly evenly in the regions of crystalline Precambrian bedrock. Its southern limit is unknown. So far there are no records from outside Fennoscandia.

L. tuomikoskii seems to grow only with Picea abies. It is characteristic of moist or slightly paludified places in upland spruce forests with a continuous, often thick, cover of Hylocomium splendens or Sphagnum girgensohnii. It is essentially a forest fungus, thriving on mor-type humus, whereas L. leonis, L. olivinus and L. auriolla are rather peatland fungi.

L. tuomikoskii is a boreal species, centred in the middle and northern boreal zones. Some occurrences are known in the northern parts of the hemiboreal zone.

\section{Phenology}

The fruiting period of L. tuomikoskii is short; in Fennoscandia it ranges from August to mid-September. The latest records shown in Fig. 17. represent scanty occurrences of poor, dwarfish basidiocarps. The cessation of fruiting depends on local climatic conditions, development being stopped almost immediately by nights with several degrees of frost. If the late summer is dry, as in 1982, the basidiocarps have no time to develop, and the autumnal rains do not stimulate basidiocarp production. L. tuomikoskii colonies are nearly always scanty; the basidiocarps seem to develop simultaneously and remontant fruiting is weak even when conditions are suitable.

\section{Discussion}

L. tuomikoskii is distinguished from L. scrobiculatus by its smaller size, lighter colour, longer marginal hairs on the young pileus, unscrobiculate stipe, flex- 

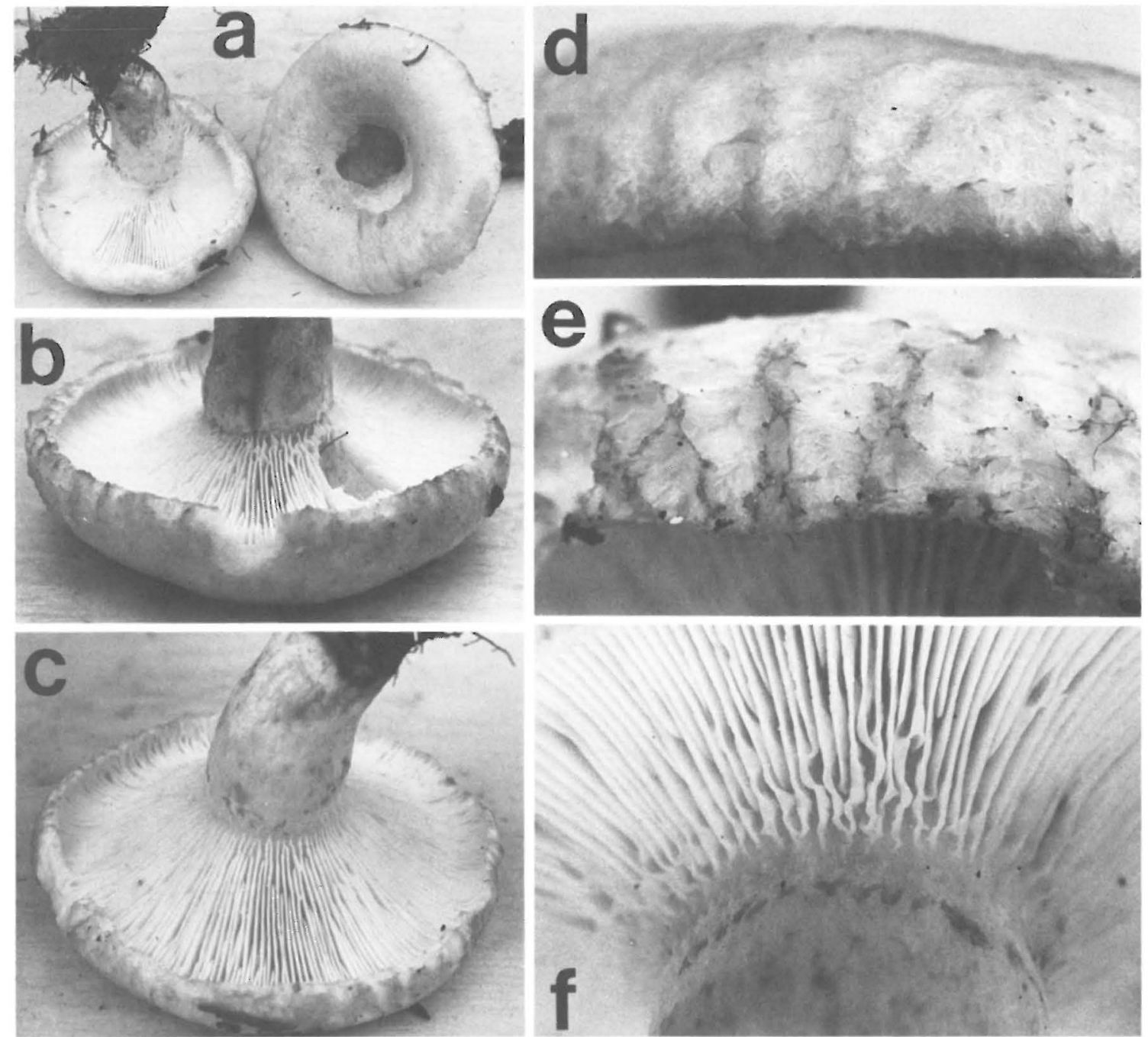

Fig. 7. Lactarius tuomikoskii. - a, c, f) Ky 81972. - b, d) Ky 81793. - e) Ky 81633.

uose and often forked, white-edged lamellae and softer context. Probably owing to the latter feature, the basidiocarps are nearly always damaged by molluscs.

From L. leonis, L. tuomikoskii is differentiated by the different hairiness at the pileus margin, and unscrobiculate stipe, from $L$. olivinus by the lack of a greenish tint, by the scattered, narrow macrocystidia and different spore ornamentation. Old and poor basidiocarps of L. auriolla may be difficult to separate from L. tuomikoskii, the spore size and ornamentation offering the only distinguishing features. Good basidiocarps are easily recognized by the form of the marginal hairs and difference in the basal part of the lamellae.

With its azonate, light yellow pileus and marginal hairs 'combed' into radial ridges, L. tuomikoskii resembles the American taxon called L. scrobiculatus var. scrobiculatus by Hesler \& Smith (1960, Smith
24494 in MICH examined). However, in the latter the stipe is more scrobiculate, the spores are smaller, their ornamentations wider, higher (up to $1.5 \mu \mathrm{m}$ ) and roughly nodulose, and the macrocystidia larger $(80-130 \times 6-11 \mu \mathrm{m})$, and more projecting $(40-80$ $\mu \mathrm{m}$, cf. p. 71). It is clearly a good species, different from L. tuomikoskii and the other American taxa of the group.

\section{Specimens examined}

Norway. Akershus: 1977 Galien (O), 1971 Kvavik (O), Torkelsen 108/73 (O). Hedmark: 1965 Guttormsen (O), Ky 6249 (H). Oppland: Stordal 15548, 15719, 16799, 16817 (O). Buskerud: Stordal 10115 (O). Hordaland: Stordal 4508 (BG, O). Sör-Tröndelag: 1951 Gjaerevoll (TRD), Stordal 8924 (TRD). Nord-Tröndelag: Ky 72002, 73002, $80461(\mathrm{H})$, Stordal 6333, 12330, 14028 (TRD). Nordland: Ky 4708, $81556(\mathrm{H})$.

Sweden. Värmland: Ky 7915 (H). Uppland: Ky $79627(\mathrm{H})$. Dalarna: Ky 6241, 79474, 79477, 79487, 49549, 80503, 80531, 


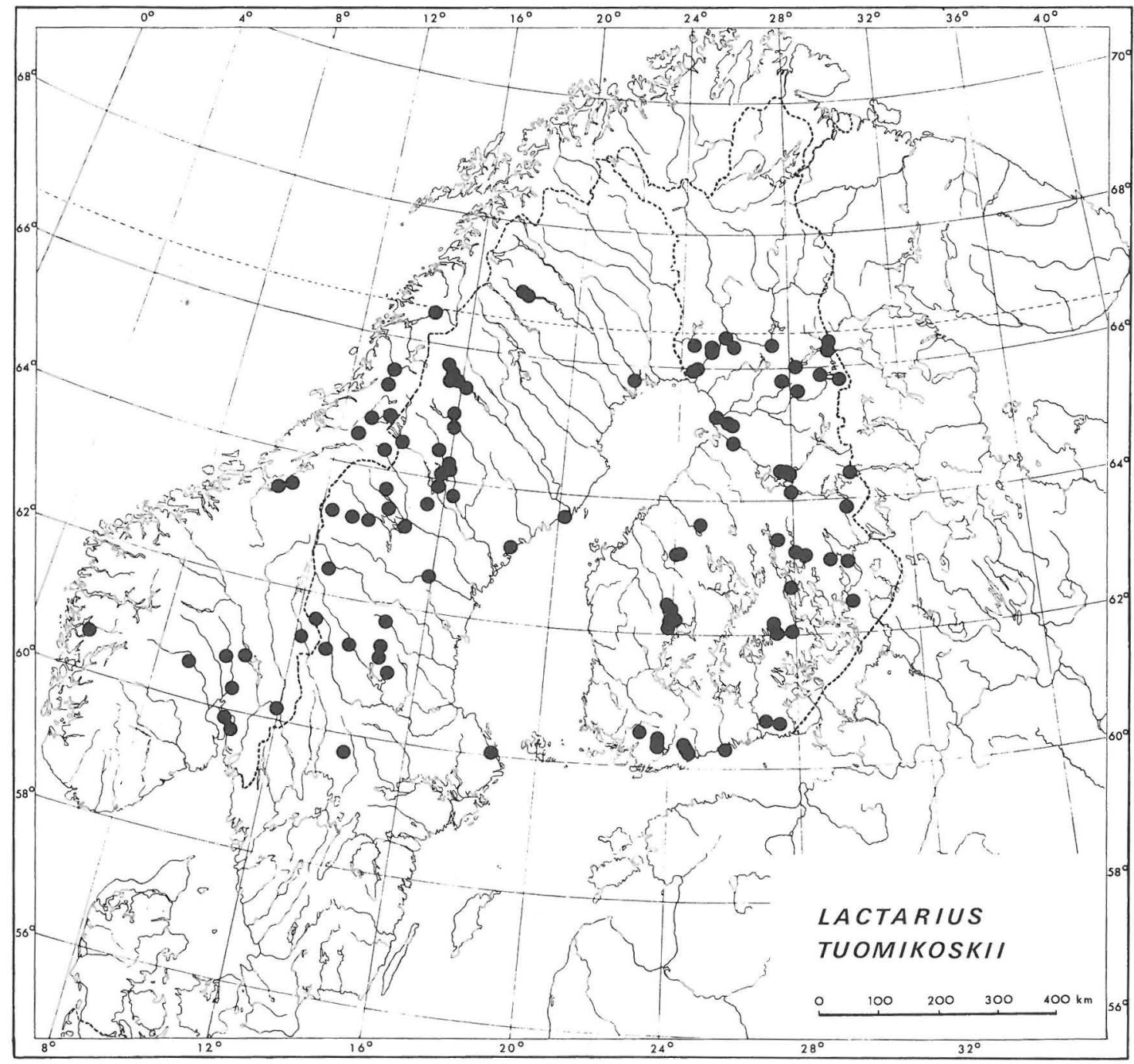

Fig. 8. Distribution of Lactarius tuomikoskii in NW Europe according to the material examined.

81405 (H). Medelpad: 1983 Carlstedt, Korhonen $5446(\mathrm{H})$. Angermanland: Korhonen $5455(\mathrm{H}), \mathrm{Ky} 79212,79235,79299$, $79321,80406,81633(\mathrm{H})$. Härjedalen: Ky $80489(\mathrm{H})$. Jämtland: Korhonen 5433, 5441, $5442(\mathrm{H}), \mathrm{Ky}$ 6319, 79391, 79406, 79453, 80436, 81605 (H), 1975 Nannfeldt (UPS), Vauras 1295 (KUO). Norrbotten: Ky 4980, $80543(\mathrm{H})$. Asele Lappmark: Ky 80392, 80401 (H). Lycksele Lappmark: Ky $80318,80334,80337,80356,80358,81577(\mathrm{H})$. Lule Lappmark: Ky 80218, $80248(\mathrm{H})$.

Finland. Varsinais-Suomi: Ky 9506, 801213, 801457, $811347,811348,83016(\mathrm{H}), 1980,1981$ Kytövuori $(\mathrm{H}), 1982$ Pajanen (H). Uusimaa: 1981 Korhonen $(\mathrm{H}), 1932,1939 \mathrm{Ny}-$ berg (H).Etelä-Karjala: 1980 Fagerström (H), 1952 Kujala (H). Etelä-Häme: Ky 2588, 79760 (H). Pohjois-Häme: Ky 2125, 2518, 66002, $81675(\mathrm{H})$. Pohjois-Savo: 1983 Issakainen (H), Korhonen $5543(\mathrm{H})$, Ky 80784, 83158, 83179, 83214 (H), 1971 Pohjola \& Mäkinen (TUR). Pohjois-Karjala: Korhonen 2008, 4156, 4203, $5522(\mathrm{H})$, Ky 80869, $83196(\mathrm{H})$, 1971 Simonen (OULU). Keski-Pohjanmaa: Ky 81788, 81793 , 81795,811267 (H). Каinuи: Ку 80568, 80604, 80606, 80654,
80686, 81889, 81909, 811247, 83298 (H). Oulun Pohjanmaa: Ky 81832 (H), 1966 (2 ex.), 1972, 1974, 1976, 1981 (3 ex.) Ulvinen (OULU). Perä-Pohjanmaa: Ky 4933, 5393, 81972 81990, 811004, 811044, $83452(\mathrm{H})$, Mäkinen 74-120, 74-133 (TUR), 1960, 1974 Tuomikoski (H), 1981 Ulvinen (OULU). Koillismaa: Ahti $27009(\mathrm{H}), 1974$ Haikonen (H), 1981 Huovinen (OULU), Korhonen 5494, 5496, 5499 (H), Ky 811165 , $811202,811216(\mathrm{H}), 1974,1979$ Ulvinen (OULU).

\section{Lactarius auriolla Kytövuori, spec. nova} Illustrations. Korhonen (1984).

Pileus 4-8 cm latus, convexo-depressus, dein infundibuliformis, margine fimbriato, mox recto dein glabro, cute pilei marginali squamis gelatinosis appressis pellita; gelatinosus, flavidus vel flavus. Latex albus, ad aeris contactum mox saturate sulphureus, in KOH aurantiacus. Sapor acer. Lamellae albae, rectae, prope stipitem rarissime furcatae. Stipes 3.5$6.5 \mathrm{~cm}$ longus, $1.2-2 \mathrm{~cm}$ crassus, cavus, siccus, pileo concolorus, basi tenuiter scrobiculatus. Sporae 7.3-9.1 × 5.4-6.6 $\mu \mathrm{m}$, 

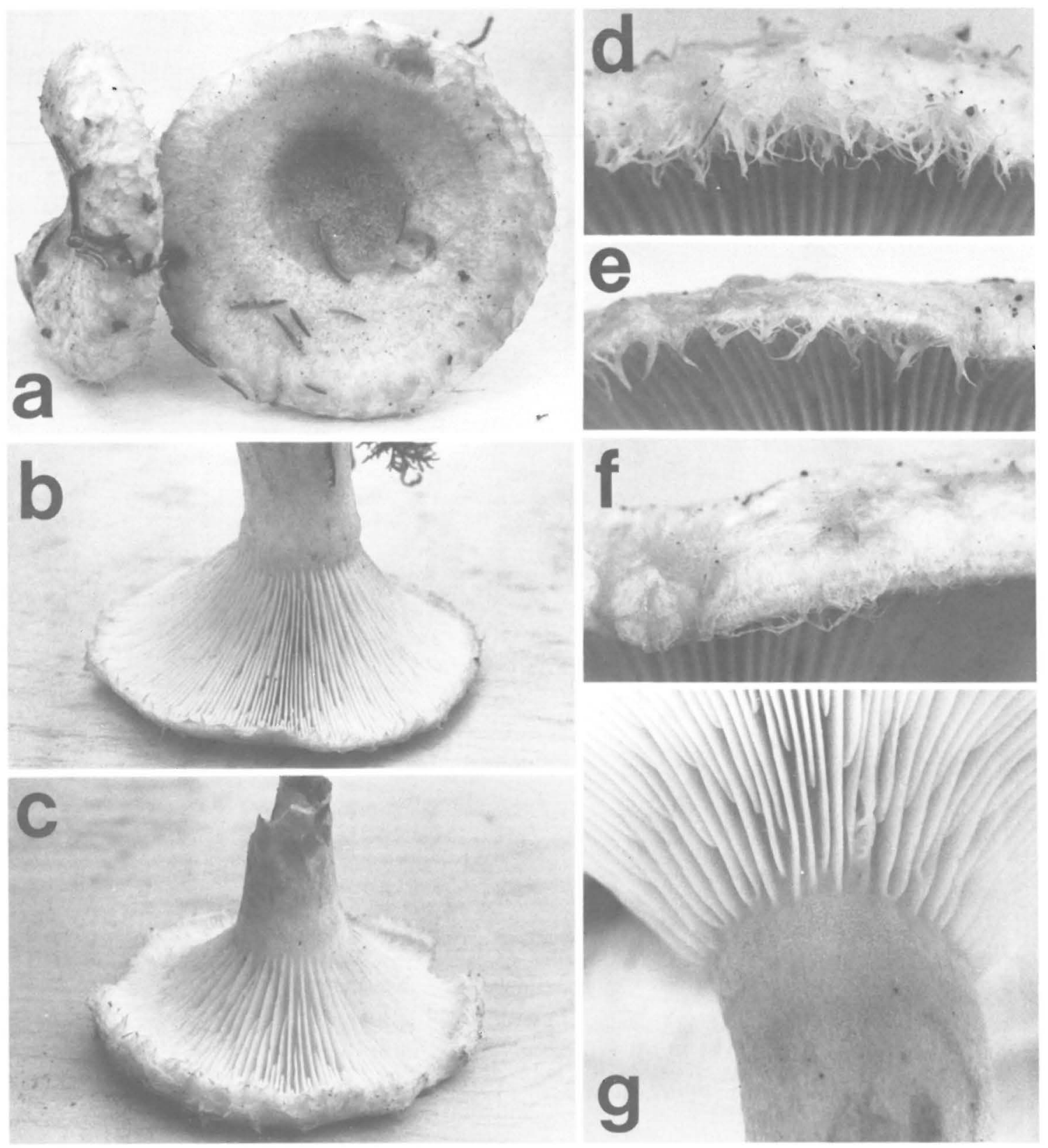

Fig. 9. Lactarius auriolla. - a, e, g) Ky 81638 (type). — b, f) Ky 81787. - c, d) Ky 811379.

late ellipsoideae vel ellipsoideae, ornamento amyloideo (sub) reticulato. Macrocystidia dispersa, 40-100 × 5-10 $\mu \mathrm{m}$, subulata, 15-50 um projecta. In Fennoscandia calciphilus, in silvis uliginosis, cum Picea abiete. Augustio et Septembri.

Holotypus: Sweden, Angermanland, Fjällsjö, S end of the lake Tåsjön, by the brook from Stortjärn, $\mathrm{S}$ of the road, narrow, rather open, alluvial spruce-hardwood swamp with Picea abies, Betula pubescens and Salix spp., $260 \mathrm{~m}$, with Lactarius scrobiculatus, L. leonis and L. olivinus, 19.VIII. 1981 P. \& I. Kytövuori 81638 ( $\mathrm{H}$, isotypi in $\mathrm{MICH}, \mathrm{K}, \mathrm{O}$, PRM, UPS, Z)
Pileus 4-8 cm broad, convex-depressed when young with margin incurved and soon outrolled, in age somewhat infundibuliform with relatively deep depression in the centre. Surface thickly slimy to gelatinous. Young margin coarsely fringed with long, somewhat scale-like, gelatinous hairs, which persist and extent over the margin even in the mature pileus with outrolled edge. Colour light yellow, maize yellow to amber yellow throughout, without darker pigmented zones but with $2-3$ narrow (less than 1 


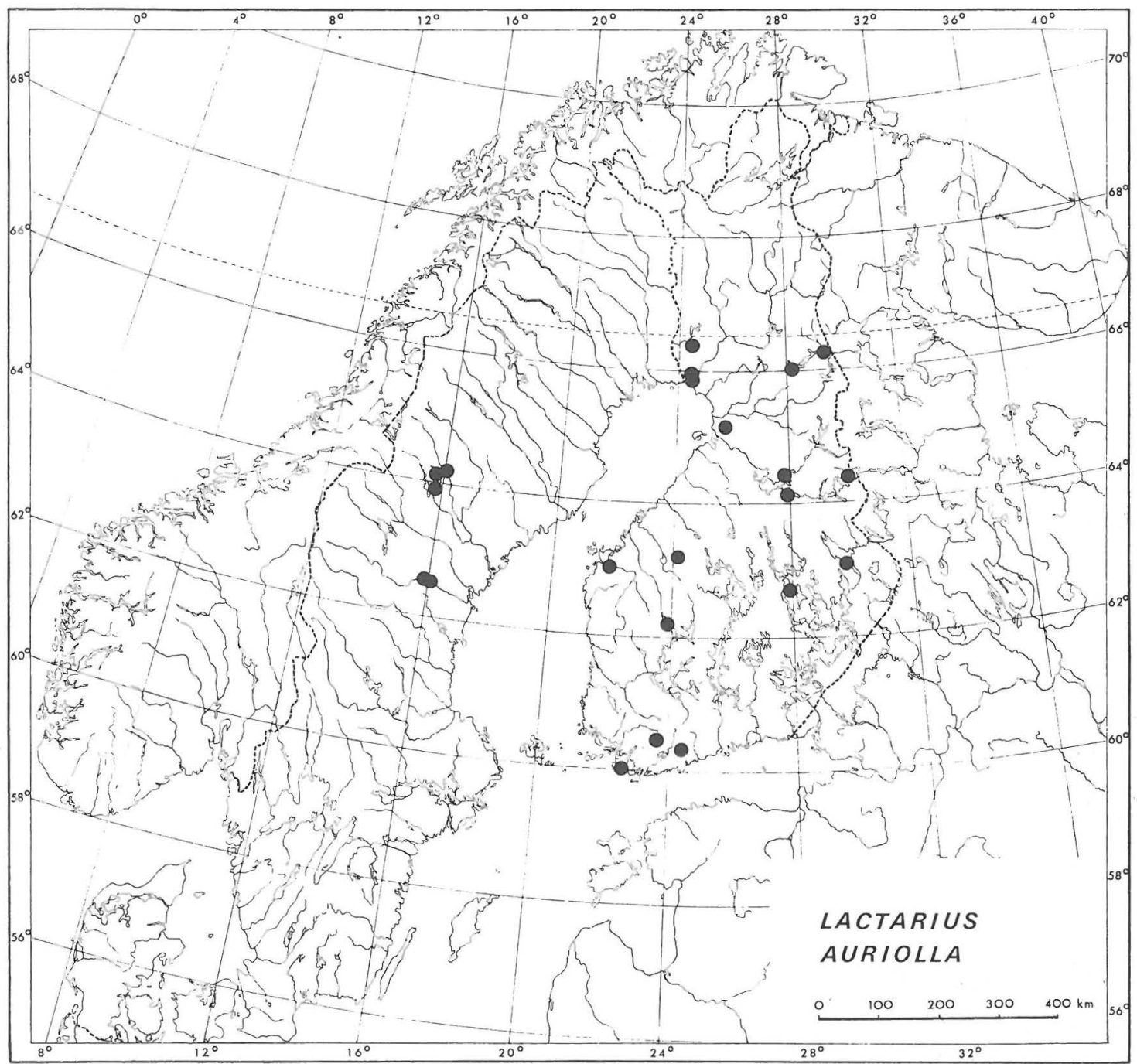

Fig. 10. Distribution of Lactarius auriolla in NW Europe according to the material examined.

$\mathrm{mm}$ wide) watery zones at the outermost whitish edge (Fig. 9f). The centre concolorous with the marginal part or slightly darker. Context rather thin, fragile, not hard. Latex scanty, white, rapidly turning sulphur yellow when exposed, orange in $\mathrm{KOH}$, acrid.

Lamellae white, rather narrow and thick, close, not or rarely forked near the stipe, straight, subdecurrent, lamellulae rather numerous.

Stipe $3.5-6.5 \mathrm{~cm}$ long, $1.2-2 \mathrm{~cm}$ thick, of even thickness or thickening upwards, hollow, whitish pruinose or \pm concolorous with the pileus, the upper part not scrobiculate, the base with large, irregular spots, the top without distinct ring or whitish tomentum, dry.

Spores $7.3-9.1 \times 5.4-6.6 \mu \mathrm{m}$, lenght/width ratio $1.23-1.45$, broadly ellipsoid to ellipsoid, with strongly amyloid ornamentation of narrow ridges forming a coarse-meshed incomplete reticulum and spotlike warts, prominences up to $0.5 \mu \mathrm{m}$ high (much more distinct than in L. leonis), plage rather small.

Basidia 31-47 × 6-9 $\mu \mathrm{m}$, 4-spored. Macrocystidia scattered, somewhat concentrated between the gills, $40-100 \times 5-10 \mu \mathrm{m}$, originating deep in the trama, subulate, with the broadest point in the hymenium, projecting $15-50 \mu \mathrm{m}$, the projecting part sometimes forked. Pseudocystidia 5-8 $\mu \mathrm{m}$ thick.

In Fennoscandia slightly calciphilous, in moist and paludified depressions in spruce or mixed forests, in rich spruce-harwood swamps. Scattered or in small groups. Only with Picea abies. Boreal, rather rare, August to September.

Distribution and ecology

L. auriolla is only slightly calciphilous in Fennoscandia, but is seldom found in infertile regions. It is rath- 
er rare in Finland, but the colonies may consist of $10-20$ basidiocarps.

The Scandinavian distribution of $L$. auriolla is less well known than that of the preceding species. Its specific status did not become clear to me until my Scandinavian excursions were over, and the records resulted from fortuitous collections. It is not yet known from outside Fennoscandia.

L. auriolla seems to grow only with Picea abies. It occurs in moist, often spring-fed or slightly paludified depressions in rich spruce forests, e.g. in habitats similar to those of L. leonis. It is unlikely to occur on wholly unpaludified upland soil.

L. auriolla is a boreal species with a perhaps more southern dristribution than most other species of the yellow group. Fig. 10 may be misleading owing to the intensive search for this species in northern Finland in the good mushroom season of 1981. Moreover the northernmost occurrences were very scanty. The southernmost localities just reach the hemiboreal zone.

\section{Phenology}

In Fennoscandia the fruiting period of $L$. auriolla lasts from early August to the beginning of October (Fig. 17). The species is sensitive to frost and the cessation of growth is dependent on the occurrence of frosty nights.

\section{Discussion}

In good condition $L$. auriolla is easily distinguished by the deeply funnel-shaped centre of the pileus, the long, gelatinous marginal hairs persisting even in the outrolled pileus, and the straight unforked lamellae. Poor basidiocarps and dried specimens may resemble L. tuomikoskil, but can be recognized by the smaller and narrower spores with lower, reticulate ornamentation, which is more regular and contains long ridges. The narrow, watery zones of this species are lacking in the other yellow species treated here. The infundibuliform appearance, presence of watery zones, gelatinous flat, marginal hairs and the spore size and ornamentation suggest that $L$. auriolla is intermediate between the yellow and white group (especially $L$. aquizonatus) within the subsection Scrobiculati.

\section{Specimens examined}

Sweden. Medelpad: Korhonen 5418, 5423, 5424a, 5449, 5454 $(\mathrm{H})$. Ängermanland: Ky $81638(\mathrm{H})$. Jämtland: Ky 79407 , $80437(\mathrm{H})$.

Finland. Varsinais-Suomi: Korhonen 4865 (H), Ky 801345 , $801463,811349,811379$ (H), 1980 Kytövuori (H). Etelä-Pohjanmaa: 1979 Kiviluoma (OULU). Pohjois-Häme: Ky 81664 (H). Pohjois-Savo: 1973 Hakala (KUO). Pohjois-Karjala: Korhonen 4212 (H). Keski-Pohjanmaa: Ky 81787, 81804, (H). Kainuu: Kу 81893, 81911, 81912, 811249 (H). Oulun Pohjanmaa: Ky 81834 (H), 1976 Ulvinen (OULU). Perä-Pohjanmaa: Ky 81965, 81974, $83453(\mathrm{H})$. Koillismaa: Ky 811204 $(\mathrm{H}), 1981$ Ulvinen (OULU).

\section{White group}

Large, pileus infundibuliform, white to slightly yellowish, azonate to zonate with narrow watery zones in the marginal part, darker pigmented zones absent.
Stipe short, not spotted or indistinctly spotted near the base. Macrocystidia scattered to rare, smaller than in the yellow group. Associated with many tree species, most often in dryish or mesic habitats.

\section{Lactarius resimus (Fr.) Fr.}

Lactarius resimus (Fr.) Fr., Epicr. Syst. Mycol.: 336. 1836. - Agaricus resimus Fr., Syst. Mycol. I: 75. 1821. - Type: not typified.

A. intermedius Fr. var. expallens Fr., Obs. Mycol. I: 58. 1815.

?L. resimus var. insipidus A.H. Smith in Hesler \& A.H. Smith, Brittonia 12: 317. 1960. - Holotype: U.S.A. Michigan, Mackinaw City, 14.IX.1957 A.H. Smith 58117 (MICH).

?L. resimus var. regalis (Peck) Peck, Ann. Rep. N.Y. State Mus. 38: 118. 1885. - ?L. regalis Peck, Bull. Buffalo Soc. Nat. Sci. 1: 57. 1873. - Holotype: U.S.A. New York, Croghan, IX. C.H. Peck (NYS).

Illustrations. Lange (1935), Neuhoff (1956), Marchand (1980), Michael et al. (1983), Korhonen (1984). - Not Ricken (1915), Bresadola (1928), Kalamees (1979), Cetto (1979).

Pileus 8-16 (-22) $\mathrm{cm}$ wide, infundibuliform with centre deeply depressed, margin inrolled when young; convex-infundibuliform with age, viscid to thinly slimy, soon nearly dry. Young margin tomentose or faintly hairy with short, narrow hairs, soon glabrous. Colour white to whitish, in age sometimes with brownish areas in the centre, azonate or in age with a few very narrow watery zones just at the edge (the zonate area less than $0.5 \mathrm{~cm}$ wide). Context rather thin, not hard, fragile. Latex scanty, white, rapidly turning sulphur yellow when exposed, orange in $\mathrm{KOH}$, acrid. Odour not distinctive.

Lamellae close, straight, sparsely forked near stipe, decurrent, whitish (alutaceous in dried specimens), lamellulae numerous.

Stipe short, $2.5-6 \mathrm{~cm}$ long, $2-3.5 \mathrm{~cm}$ thick, not hard, fragile, \pm of even thickness, hollow, white, pruinose, brownish when bruised, not scrobiculate, dry, coarsely hairy at base.

Spores $7.7-10 \times 5.7-7 \mu \mathrm{m}$, lenght/width ratio $1.29-1.45$, broadly ellipsoid, with amyloid ornamentation of long and short ridges forming an incomplete, broken reticulum and isolated warts, prominences up to $0.8 \mu \mathrm{m}$ high, apiculus distinct, plage distinct.

Basidia 32-45 × 7-10 $\mu \mathrm{m}, 4$-spored. Macrocystidia scattered, somewhat concentrated between the gills, $45-90 \times 5-8 \mu \mathrm{m}$, aculeate to subulate, with the broadest point in or outside the hymenium, often without any subapical contrictions, projecting 15-50 $\mu \mathrm{m}$. Pseudocystidia $3-6 \mu \mathrm{m}$ thick.

In Fennoscandia with wide ecological amplitude, in dryish to mesic mixed forests with at least Betula and Pinus sylvestris. Scattered or in small groups. August to September.

Distribution and ecology

In Fennoscandia Lactarius resimus is an ecologically wide-ranging species, and it occurs \pm evenly throughout Finland except in the north, being found both in fairly acid and infertile sites and in fertile or calcareous areas. However, it is common only in the eastern 

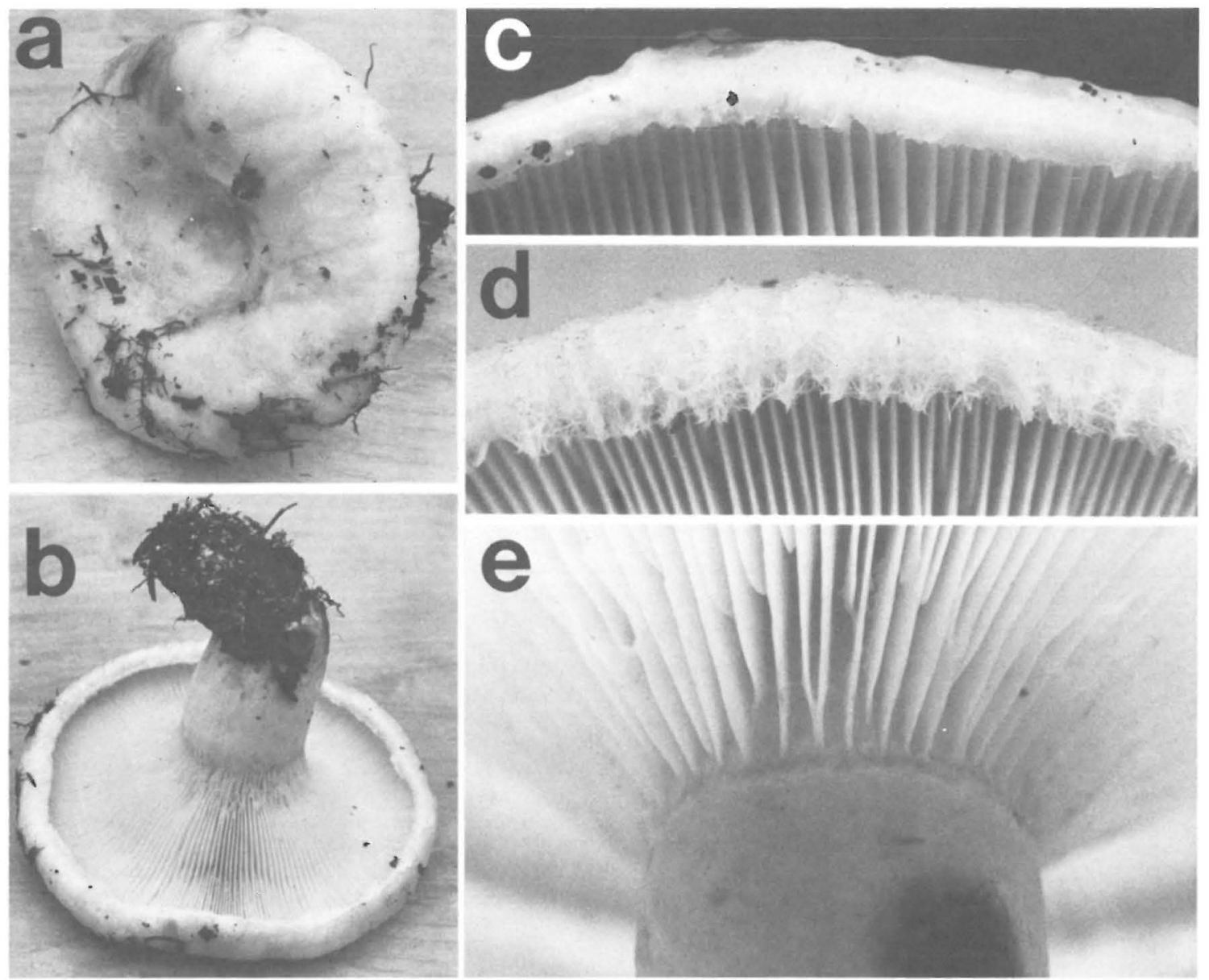

Fig 11. Lactarius resimus. — a, b) Ky 81836. - c) Ky 81805. — d, e) Ky 81976.

part of the country.

In Scandinavia L. resimus seems to be rare, with more frequent records only around Stockholm, but it is apparently fairly widespread, at least in the southern part of Sweden, as was first noted by Fries (1821). Except for the Stockholm - Uppsala region, Sweden is poorly collected as regards the fleshy fungi and $L$. resimus has such a wide range of habitats, that a special search during excursions is much less effective than in the yellow species. However, the difference in its frequency between Scandinavia and Finland is so striking that the species must have a somewhat eastern continental dirstribution. According to Zuev (1961), L. resimus is an important edible mushroom in the U.S.S.R and is reported to be very common in many regions there. Vasil'eva (1973) reports the species from the Far East. However, it must be kept in mind that records of $L$. resimus in the literature evidently also relate to $L$. aquizonatus.

L. resimus seems to be rarer further south. In Estonia it is the rarest species of the group according to the material of TAA. In Central Europe it is occasionally found in the NE part and in the mountains (cf.
Neuhoff 1956, Michael et al. 1983, Krieglsteiner 1984). The 48 Czechoslovakian specimens of the section Scrobiculati borrowed from Prague (PRM) include only three specimens of $L$. resimus

For the North American distribution, see below.

L. resimus is often reported to be a mycorrhizal fungus of Betula (cf. Neuhoff 1956). In Fennoscandia I have never seen it in pure Betula stands, but always in mixed forests with Betula and conifers, most often Pinus sylvestris (cf. Michael et al. 1983). Its dependence on Betula may be confirmed by its concentration in eastern Finland, where slash and burn cultivation was practised fairly recently and mixed forests of Betula and conifers are common.

$L$. resimus has its maximum occurrence in the southern and middle boreal zones, becoming rarer in the hemiboreal zone and extending northwards near the southern limit of the northern boreal zone as defined by Ahti et al. (1968). It is noteworthy that no specimens have been collected in the Kuusamo area in NE Finland, which is mycofloristically one of the bestknown areas in Finland. It has actually been reported from Kuusamo by Tuomikoski (1953) and Ulvinen et 


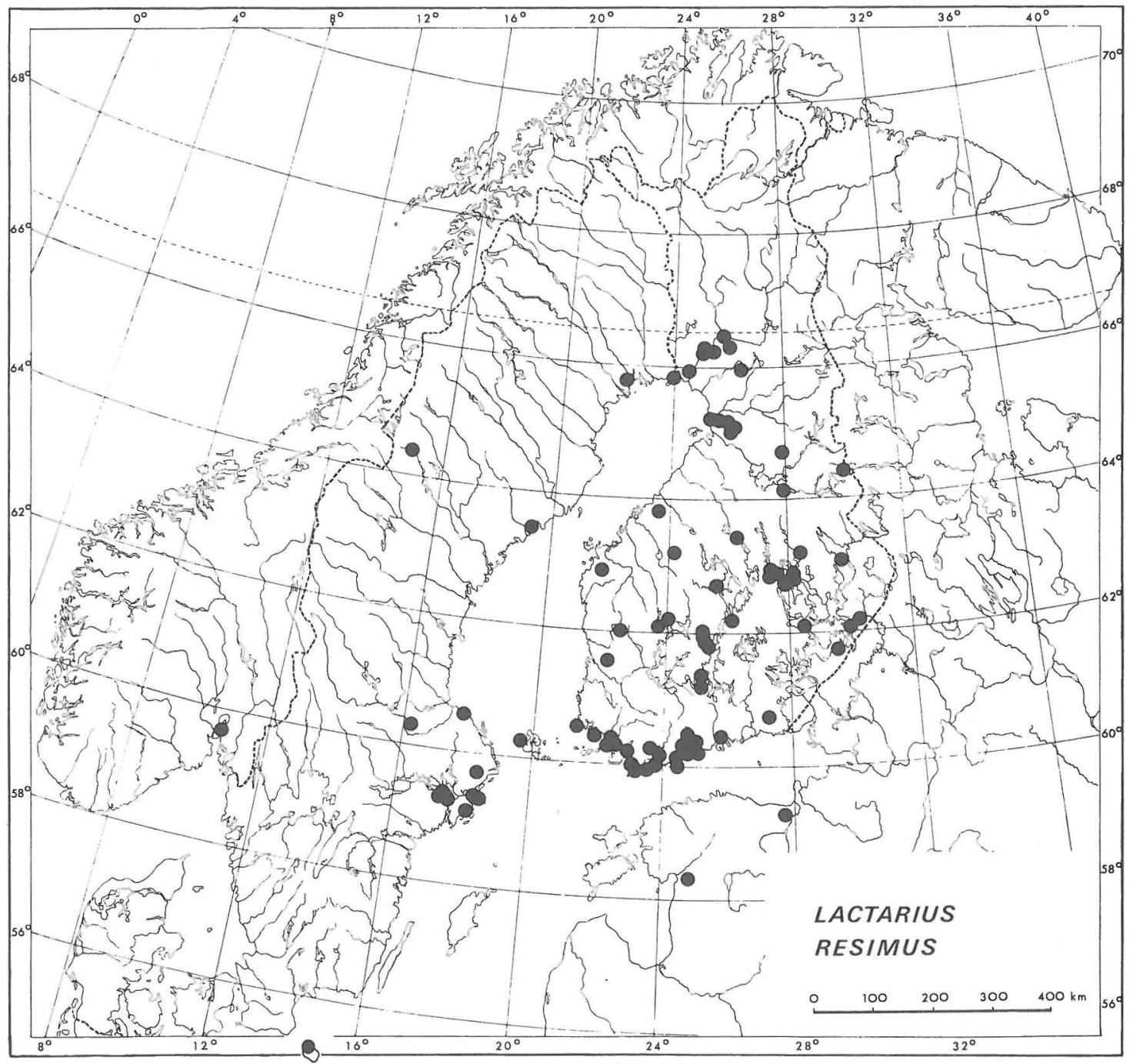

Fig. 12. Distribution of Lactarius resimus in NW Europe according to the material examined.

al. (1981), but no vouchers exist and the records do not appear to be reliable. Further north, in the mountain birch forests of Fennoscandia, the species has never been found.

\section{Phenology}

In Fennoscandia the fruiting period of $L$. resimus starts at the beginning of August and ceases in late September - early October. The latest records in Fig. 17 represent poor basidiocarps, which were almost dead when collected. The species does not endure strong frost, but is not as sensitive as most species of the yellow group.

\section{Discussion}

L. resimus can be separated from the other species of the white group by its whiter colour, softer and thinner context, pileus margin which is tomentose or, on- ly in very young basidiocarps, minutely hairy, at first azonate and later with one or two watery zones only at the outmost edge, by its larger spores, and long macrocystidia. From the species of the section Albati (Bat.) Singer it is distinguished by its latex, which turns yellow when exposed and by the stronger spore ornamentation.

Among dried specimens some heterogeneity seems to exist. Some specimens have a thin context and are nearly pure white; others have a thicker and harder context, more yellowish colour and denser, less white la mellae. Whether these differences are real or merely caused by different drying conditions remains to be decided.

L. resimus is frequently sited in the European literature, but the reports are not reliable as they often relate to other species of the group. The descriptions by Fries $(1821,1836,1863)$ emphasize the glabrous 
and azonate pileus margin of $L$. resimus, referring without doubt to the taxon here called $L$. resimus $\mathrm{s}$. str., although the margin is depicted as somewhat hairy (Fries 1877). His phytogeographical notes support this interpretation.

In North America Hesler \& Smith (1960) recognized $L$. resimus with three varieties: var. resimus, var. insipidus A.H. Smith and var. intermedius A.H. Smith (not L. intermedius (Krombh.) Cooke). They later (1979) united var. resimus and var. intermedius, and included var. insipidus in L. resimus var. regalis Peck.

The taxonomy of the group seems to be rather complicated. L. resimus var. insipidus is closest to the Fennoscandian material of $L$. resimus, but its taste is described as mild. In my limited taste tests of $L$. resimus, all the basidiocarps were definitely acrid. L. regalis Peck is reported to be acrid, but in the holotype the ornamentation of the spores seems to be more reticulate, the spores are slightly smaller and the macrocystidia somewhat shorter $(40-70 \times 5-8 \mu \mathrm{m}$, projecting $11-35 \mu \mathrm{m}$, not seen by Hesler \& Smith 1979) than in the European L. resimus. The condition of the type specimen of $L$. regalis is not good and the macroscopical appearance is indistinct. It is not certain whether L. resimus var. insipidus and $L$. regalis are identical or belog to L. resimus s. str., but all these taxa are very closely related and clearly different from L. resimus var. resimus sensu Hesler \& Smith (1960) and $L$. resimus var. intermedius.

In the $L$. resimus material cited by Miller (1982), one basidiocarp of Miller 18259 is perhaps L. resimus s. str. (or L. r. var. insipidus) and Miller 15728 is perhaps L. aquizonatus (or L. r. var. intermedius), whereas Miller 18265 and the other basidiocarp of Miller 18259 evidently represent an undescribed species.

\section{Specimens examined}

Denmark. Bornholm: 1947 Möller (C).

Norway. Akershus: 1966 Kvavik (O).

Sweden. Södermanland: 1936 Cortin (S), 1949 Haglund (S), 1948 Rundquist (S), 1963, 1967 (2 ex.) Suber (S). Stockholm: 1912, 1915 Romell (S). Uppland: 1945 Fåhraeus \& Stenlid (UPS), 1890 Kugelberg (UPS, S), 1965 Persson (S), 1896 Romell (S), 1946, 1963 Suber (S), Dalarna: 1974 Persson (UPS). Angermanland: Ky 5029 (H). Jämtland: Ky 80440 (H). Norrbotten: Ky 4823 (H), 1951 Pekkari (UPS).

Finland. Ahvenanmaa: 1963 Siltanen et al. (TUR). Varsinais-Suomi: 1972 Alava \& Alho (TUR), 1979 Alho (TUR), 1982 Federley (H), 1982 Heimo (TUR), 1960 Kallio (TUR), Korhonen $4899(\mathrm{H})$, Ky $9505(\mathrm{H}), 1978$ Pohjola \& Kupias (TUR), 1972, 1981 Tuomikoski (H), 1957 Schulman (H), 1979 Ulvinen (OULU), Uusimaa: Askola 717 (H), 1957 Frey (H), 1980 Issakainen (H), 1980 Federley (H), 1980 Härkönen $(\mathrm{H}), 1949$ Jalas $(\mathrm{H})$, Korhonen $2370(\mathrm{H}), \mathrm{Ky} 79693$, 79721, 79736, $801512(\mathrm{H}), 1980$ Kytövuori (H), 1942 (2 ex.), 1943 (2 ex.) Malmström (H), 1950 Mäkitalo (H), 1942 Nyberg $(\mathrm{H})$, Saarenoksa $52581(\mathrm{H})$. Etelä-Karjala: 1979 Fagerström (H), 1965 Tiensuu (H). Satakunta: Mäkinen 81-618 (TUR). Etelä-Häme: 1871 (2 ex), 1878, 1879 Karsten (H), 1966 (2 ex.), 1967, 1970 Koskinen (H), Ky $6491(\mathrm{H}), 1980$ Mäki-Paakkanen (H), 1972 (2 ex.), 1974 Tuomikoski (H), 1981 Vänskä (H). Etelä-Savo: Ky 811470 (H), 1979 Soc. Mycol. Fenn. (KUO). Etelä-Pohjanmaa: 1979 Heikkilä (OULU), Ky 83058 (H). Pohjois-Häme: 1981 Harmaja (H), 1966 Kankainen (TUR), Ky 2596, 8587, 70001 (H). Pohjois-
Savo: 1966, 1971 Hakala (TUR), 1967 Hämäläinen (KUO), Ky 80823, 80836, 80900 (H), 1966 Räsänen (3 ex. TUR), 1972 Savolainen (KUO), 1981 Vilmusenaho (OULU). Pohjois-Karjala: Korhonen 4150, 4151, 4153, 4155, 4208, 4209, $4215,4216,5534,5535(\mathrm{H}), \mathrm{Ky} 80868,80961,801600(\mathrm{H})$. Keski-Pohjanmaa: Ky 81805, $811293(\mathrm{H}), 1981$ Mansikkamäki (OULU). Kainuu: Ky 81913,81933, 811250 (H). Oulun Pohjanmaa: 1977 Huttunen (OULU), 1970 Häkkinen (OULU), Ky 81836 (H), 1966 Ohenoja (OULU), 1971, 1976, 1981 (3 ex.) Ulvinen (OULU), 1979 Vahva (OULU). Perä-Pohjanmaa: Ky 4897, 4943, 81976, 81991, $811005(\mathrm{H}), 1981$ Ohenoja (OULU), 1967 Sääskilahti (OULU), 1974 Tuomikoski (H), 1974 Ulvinen (OULU).

U.S.S.R. Estonian S.S.R.: 1963, 1966 Kalamees (TAA).

\section{Lactarius aquizonatus Kytövuori, spec. nova}

?L. resimus var. intermedius A.H. Smith in Hesler \& A.H. Smith, Brittonia 12: 317. 1960. - Holotype: U.S.A. Idaho, Stanley, Stanley Lake, 18.VII.1954 A.H. Smith 46231 (MICH).

Illustrations. Korhonen (1984).

Pileus 9-20 (-25) cm latus, convexo-depressus vel infundibuliformis, margine involuto, dein recto, gelatinose squarroso, dein glabro, cute pilei marginali squamis gelatinosis squarrosis vel appressis pellita; gelatinosus, albidus vel pallide ochraceus (color intentior in pileis exsiccatis), zonis aqueis angustis marginaliter zonatus. Latex albus, ad aeris contactum mox saturate sulphureus, in KOH aurantiacus. Sapor acer, odor dulcidulus, in pileis exsiccatis manifeste distinctus. Lamellae confertae, rectae, tenuiter deccurrentes, exiliter salmoneae (color intentior in pileis exsiccatis). Stipes $2.5-6 \mathrm{~cm}$ longus, 2-4.5 $(-7) \mathrm{cm}$ crassus, cavus, siccus, pallidus, basi tenuiter scrobiculatus. Sporae 6.8-8.8 $\times$ 4.8-6.1 $\mu \mathrm{m}$, ellipsoideae, ornamento amyloideo (sub)reticulato. Macrocystidia rara, 30-90 × 5-9 $\mu \mathrm{m}$, aculeata vel subulata, $0-50 \mu \mathrm{m}$ projecta. In Fennoscandia calciphilus, in silvis aridis, humidis et uliginosis, cum Pino sylvestri et Betula. Augustio et Septembri.

Holotypus: Finland, Puolanka, Väyrylä, Kurikkavaara, Pääkkö, $\Gamma$ side of Iso Vuorijärvi, sloping rich forest on schistose bedrock with Picea abies, Pinus sylvestris, Juniperus communis, $180 \mathrm{~m}$, 30. VIII.1981. I. Kytövuori $81934(\mathrm{H}$, isotypi in MICH, K, O, PRM, UPS, Z).

Pileus 9-20 (-25) cm wide, convex-depressed to infundibuliform with the centre sligthly less depressed than in L. resimus, margin inrolled when young, outrolled with age, thickly gelatinous in the marginal part. Young edge fringed with recurved, obtuse, gelatinous scales, which are white or colourless, later turning pale yellowish; in age the margin glabrous, but marginal surface (sometimes up to the centre) covered with gelatinous scales appressed to recurved, in rainy weather swelling into a thick gelatinous layer. Colour white to pale yellowish (deepened in dried specimens), the marginal part with age becoming broadly zonate with narrow $(1-2 \mathrm{~mm})$ watery zones, in young basidiocarps the zones more restricted to the edge; pigmented zones lacking. The centre concolorous with the margin, sometimes with brownish flecks, azonate or sometimes zonate in old dried basidiocarps. Cotext firm, brittle, not very hard, zonate with watery zones. Latex white, rapidly turning sulphur yellow when exposed, orange in $\mathrm{KOH}$, acrid. Odour rather strong, fruity, especially in old basidiocarps, sweetish in dried basidiocarps.

Lamellae close to crowded, straight, decurrent, sparsely forked near the stipe, whitish with clear salmon tint (salmon colour deepened in dried basidiocarps), lamellulae numerous. 

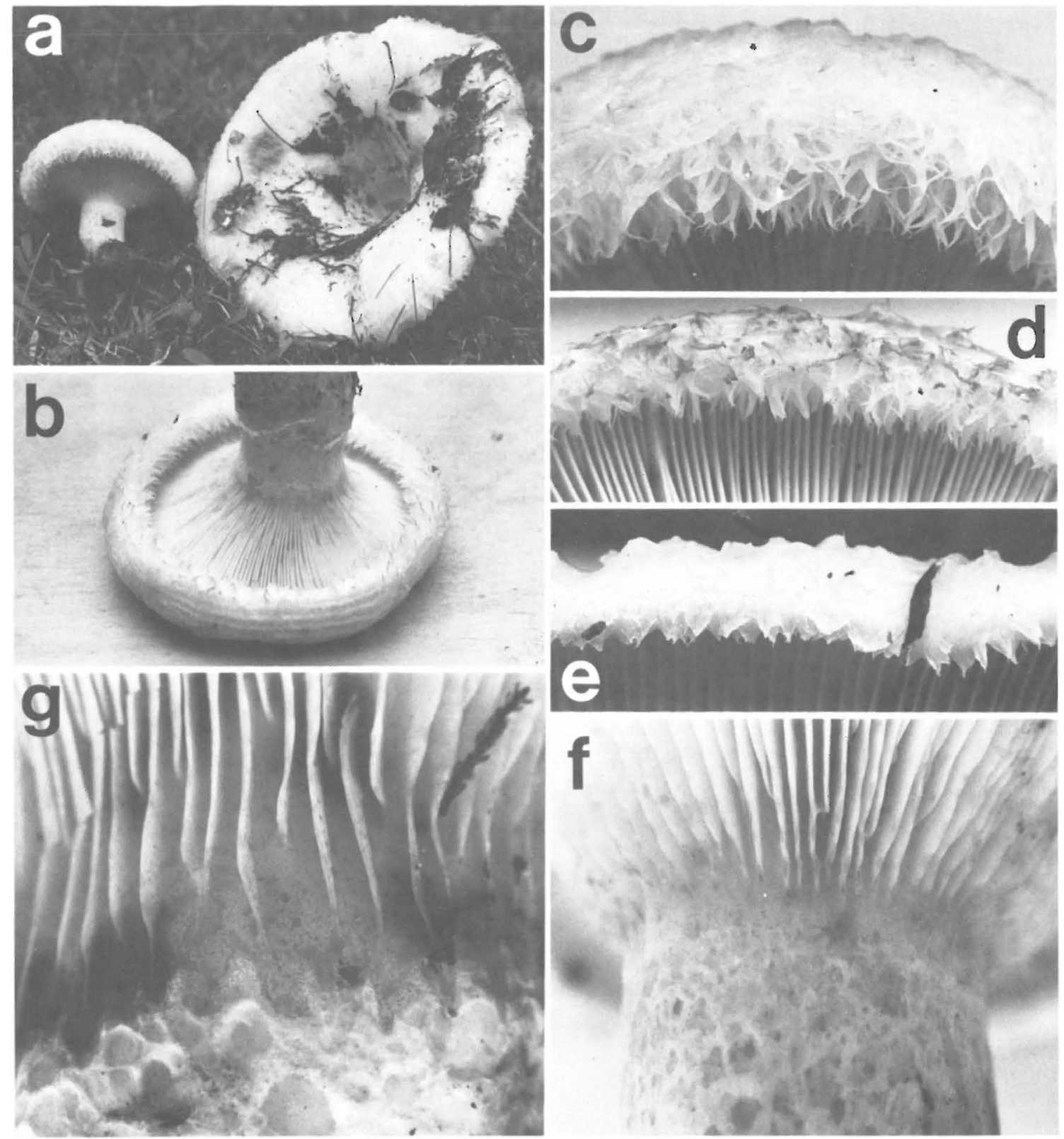

Fig. 13. Lactarius aquizonatus. — a, c, e) Ky 81797. - b) Ky 81608. — d) Ky 811294. - f) Ky 81932. - g) Ky 81796. — c, d) Very young basidiocarps with exceptionally long and narrow hairs, g) Base of lamellae of a basidiocarp with exceptionally stout stipe, scale about the same as in $\mathrm{f}$.

Stipe $2.5-6 \mathrm{~cm}$ long, 2-4.5 (-7) $\mathrm{cm}$ thick, of even thickness or thicker in middle, hollow, dry, concolorous with pileus, basally shallowly spotted, coarsely hairy at base.

Spores $6.8-8.8 \times 4.8-6.1 \mu \mathrm{m}$, length/width ratio $1.38-1.58$, ellipsoid, with strongly amyloid ornamentation of narrow ridges forming an incomplete reticulum (more reticulate than in the other species treated here) and some isolated warts, prominences up to $0.5 \mu \mathrm{m}$ high, plage distinct, not large.

Basidia 33-41 × 7-9 $\mu \mathrm{m}, 4$-spored. Macrocystidia very rare, concentrated between the gills, 30-90 $\times 5-9 \mu \mathrm{m}$, aculeate-subulate, often with obtuse apex and difficult to separate from the pseudocystidia, projecting up to $50 \mu \mathrm{m}$. Pseudocystidia $4-7 \mu \mathrm{m}$ thick.

In Fennoscandia calciphilous, in dry and dryish heath and grass-her's forests, in swampy depressions. With many tree species, both hardwoods and coni- 


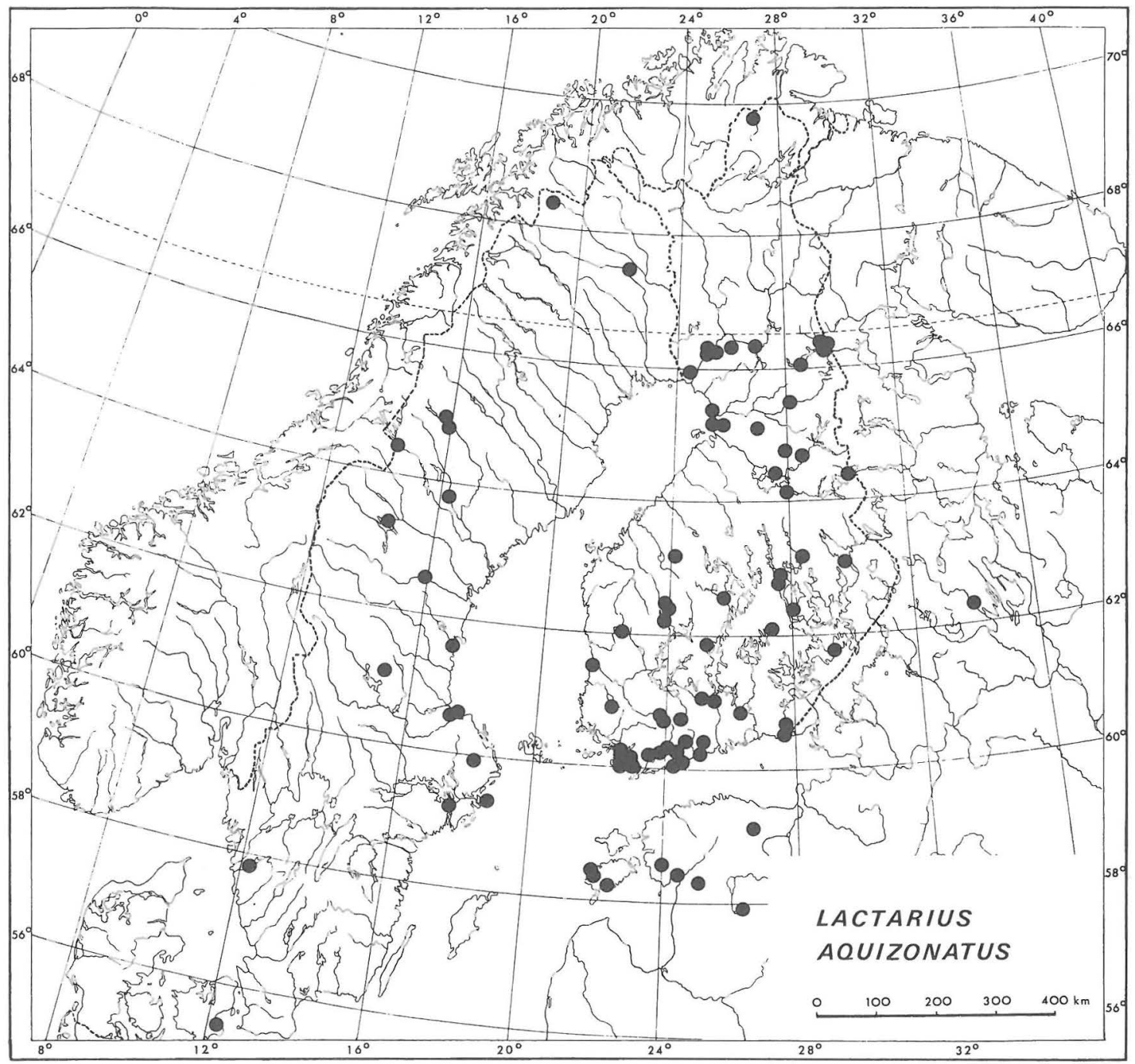

Fig. 14. Distribution of Lactarius aquizonatus in NW Europe according to the material examined.

fers. August to October.

Distribution and ecology

In Fennoscandia Lactarius aquizonatus is a calciphilous species, which is commonest in fertile areas and rarer in regions with poorer soil. Though not infrequent in the fertile areas of Kuusamo and the Rovaniemi - Tornio region in North Finland, it is less common and abundant there than $L$. scrobiculatus. In South Finland its occurrence is somewhat exaggerated in Fig. 14, as the small limestone areas were systematically checked by me (cf. L. scrobiculatus). In ordinary Finnish forests it is scattered or rare throughout the country.

Like $L$. resimus, $L$. aquizonatus seems to be rare in Scandinavia. Again, it is difficult to guess how much this is due to poor herbarium collections. The scattered and concealed habitats, wide ecological ampli- tude, and uneven fruit body production (see below) make the species difficult to search for. It has not yet been found in Norway. According to the specimens in TAA, L. aquizonatus is the commonest species of the subsection Scrobiculati in Estonia.

In Central Europe L. aquizonatus is not known. The literature is useless in this respect and no specimens from that region exist in the Fennoscandian herbaria. The collections of PRM, the only Central European material seen by me, did not include $L$. aquizonatus.

L. aquizonatus has wider ecological ampitudes than the other species treated here as regards soil fertility, moisture and the species composition of the forest. It grows in dry upland-type forests or thickets dominated by Pinus sylvestris with Betula, Salix and Populus tremula. Some specimens were collected in nearly pure Pinus sylvestris woods, and one (Korhonen 
5469 ) in open mountain birch forest with Betula nana. It also grows in moister spruce-dominated forests, in swampy depressions and in spruce-hardwood swamps by brooks and lakes. Moist or paludified habitats are more typical in the northern part of its range.

In the study area L. aquizonatus seems to occur from the hemiboreal zone up to the hemioroarctic zone. It must presumably be rarer in the temperate zone.

\section{Phenology}

In Fennoscandia the fruiting season of $L$. aquizonatus begins in late July and lasts to mid-October (Fig. 17). The colonies may be fairly large, as they comprise basidiocarps of different age and fuiting is prolonged. The species is not sensitive to short frosty periods. $L$. aquizonatus fruits unevenly, especially in infertile habitats, where it is orthewise scanty. It may produce fruit bodies in successive years, if the summer is suitable, but often it seems to be absent for many years without any clear climatic cause.

\section{Discussion}

In good conditions and moist weather L. aquizonatus is easily recognized by its gelatinous scales, broadly watery-zonate marginal part of the pileus, crowded, weakly salmon lamellae and the spotted base of the stipe. The sweetish odour is also distinctive, especially in old basidiocarps, and differentiates the species from the rest of the subsection, except $L$. citriolens. The whole appearance, especially the watery zonation of the pileus, is like that of $L$. controversus (Pers.: Fr.) Fr., which, however, has differently tinted lamellae and white, unchanging latex.

In properly dried specimens the yellowish colour of the pileus and the salmon tint of the lamellae, especially the latter, are much stronger than in fresh basidiocarps, making the species easier to distinguish from $L$. resimus. In dried basidiocarps the sweetish odour is disagreeably stong. The watery zones are not visible in dry condition, but may sometimes be seen as small concentric folds, or in very old basidiocarps as coloured zones, which then extend to near the pileus centre. The scales can usually be seen in dried basidiocarps, at least when magnified. Microscopically, L. aquizonatus is best identified by its reticulate spores, which are small and narrower than in any other European species in the subsection.

In North America, L. resimus var. intermedius A.H. Smith best corresponds to L. aquizonatus. The holotype has a slightly yellowish pileus, salmon lamellae, small and ellipsoid spores, and the pileus margin with some gelatinous hairs, though these are sparser and smaller than in the Fennoscandian material. Unfortunately the original odour was impossible to detect because of strong-smelling substances used against herbarium insects. The original description disagrees in some respects with our material. Hesler \& Smith (1960) write: 'Pileus ... viscid, faintly zonate to azonate ..., taste mild..' L. aquizonatus has the thickest pileal gelatinous layer in the white group, the taste is definitely acrid and the watery zones of the pileus are a striking feature. More research on the variation in
North America is needed to solve the exact identity of L. resimus var. intermedius. Some specimens (Vermont, Burlingham, Lact. N. Am. Fasc. I no. 7 s.n. Lactaria resima, in S; and Ontario, J.M. Elliott s.n. L. resimus, 107363 in UPS) are very like the Fennoscandian material, also resembling it in the scales and odour, which indicates that L. aquizonatus occurs in North America.

In their monograph (1979) Hesler \& Smith united $L$. resimus var. intermedius with their former $L$. resimus var. resimus. The latter is a yellowish fungus, whose pileus margin has tufts of long, narrow, not clearly gelatinous hairs, and the spores small and broadly ellipsoid. The taxon is evidently an American species not found in Europe and not as closely related to $L$. resimus var. intermedius as is L. aquizonatus.

Hesler \& Smith's selection of the type variety of $L$. resimus is somewhat surprising. They wrote (1979): 'We find that Ricken's (1915; p. 27) description covers our material the best', but overlooked the fact that Ricken's $L$. resimus had already been reidentified by Neuhoff (1956) and Pouzar (1968) as L. citriolens Pouzar (not found in North America).

L. delicatus Burl. with a yellowish, watery-zonate pileus, basally scrobiculate stipe, acrid taste and strong odour somewhat resembles $L$. aquizonatus, but is clearly differentiated by the subglobose, roughly ornamented spores and abundant broad macrocystidia. L. pseudodelicatus A.H. Smith, placed in the present section by Hesler \& Smith (1960), has spores resembling those of $L$. aquizonatus, but differs in the abundant broad macrocystidia. L. scrobiculatus var. pubescens A.H. Smith has spores very like those of $L$. aquizonatus, but is distinguished by the tomentose, azonate and antimony yellow pileus.

\section{Specimens examined}

Denmark. Sjaelland: 1954 Hansen (C).

Sweden. Västergötland: 1960 Karlvall (GB). Södermanland: 1903 Romell (S). Uppland: 1952 Haglund (S), 1963 Jahn (UPS), Ky 79618 (H), 1949 Rydgerg \& Haglund (S) Dalarna: Ky $83532(\mathrm{H})$. Gästrikland: Ky $79593(\mathrm{H})$. Hälsingland: Ky $82534(\mathrm{H})$. Medelpad: Korhonen $5422(\mathrm{H})$. Angermanland: Ky $79300(\mathrm{H})$. Jämtland: Ky 5276, $81608(\mathrm{H})$. Asele Lappmark: Ky 80395, 80402 (H). Torne Lappmark: Korhonen 5469, Ky $80124(\mathrm{H})$.

Finland. Varsinais-Suomi: Korhonen 4861, 4898 (H), Ky $6443,801146,801159,801281,801314,801347,801375$, $801407,801425,811381,811416(\mathrm{H}), 1961$ Toppari $(\mathrm{H})$. Uusimaa: Askola $785(\mathrm{H}), 1980$ Issakainen $(\mathrm{H}), 1978$ Kantola (H), 1952 Kujala (H), Ky 9383, 811307 (H), 1980 Saarikivi (H). Etelä-Karjala: 1977 Fagerström (H), 1970 Rintanen (H). Satakunta: 1957, 1961, 1962 Kallio (TUR), 1982 Kinnunen (H). Etelä-Häme: 1866 Borenius $(\mathrm{H}), 1979$ Kangas $(\mathrm{H}), \mathrm{Ky} 79875,811570(\mathrm{H}), 1972$ Tuomikoski (H), 1883 Vainio (H). Etelä-Savo: 1951 Tuomikoski (H). Etelä-Pohjanmaa: Ky 83059 (H). Pohjois-Häme: Ky 2288, 66003, 79794 , 81657 (H), 1971 Leskinen \& Ulvinen (OULU). Pohjois-Savo: 1966 Hakala (TUR), 1972 Hakala (KUO), Ky 83139 (H), 1903 Lönnbohm (KUO), 1903 Söderlund (KUO). PohjoisKarjala: Korhonen 4149, 4210 (H), Ky 80873 (H). KeskiPohjanmaa: Ky 81796, 81797, 81806, 81807, 811294 (H). Kainuu: Ky 81914, 81932, 81934, 811251, 83315 (H), 1981 Ojanen (OULU), 1979 Rintanen (OULU). Oulun Pohjanmaa: Ky $81835(\mathrm{H}), 1965$ Montin (OULU), 1981 Myllylä (OULU), 1981 Tervonen (OULU). Perä-Pohjanmaa: Ky 4896, 81977, 81992, 811006, $83420(\mathrm{H}), 1974$ Tuomikoski 
(H). Koillismaa: 1974 Huovinen (OULU), Korhonen 1580 , $1941,4080,5481,5492,5520(\mathrm{H}), \mathrm{Ky} 811083,811103$, $811114,811183,811218(\mathrm{H}), 1974$ Tuomikoski (2 ex. H), 1964 1970, 1974 (2 ex.) Ulvinen (OULU), 1966 Viramo (2 ex. OULU). Inarin Lappi: 1960 (2 ex.), 1961, 1964 Kallio (TUR).

U.S.S.R. Karelian A.S.S.R.: 1977 Kalamees et al. (TAA). Estonian S.S.R.: 1957, 1963, 1966, 1977, 1979, 1980 Kalamees (TAA), 1977 Kalamees et al. (TAA), 1979 Vaasma (TAA).

\section{Lactarius citriolens Pouzar}

L. citriolens Pouzar, Česká Mykologie 22: 20. 1968. - Holotype: Czechoslovakia, Karlštejn, ap. domum venatorium 'America' dictam, in Querco-Carpineto, solo calcareo, 14. VIII.1965 V. Jechová et Z. Pouzar (PR 618830).

Illustrations. Cooke 1888, Neuhoff 1956, Pilát \& Ušák 1959 (all as L. cilicioides), Kalamees 1979, Marchand 1980, Phillips 1981, Michael et al. (1983), Korhonen (1984). - Not Cetto 1979.

Large and robust. Pileus $10-22 \mathrm{~cm}$ wide, convex, deeply depressed in the centre, the edge compactly inrolled when young; with age infundibuliform; slimy. Young margin coarsely bearded with long (to short), not gelatinous, hairs, some of which usually still present in the edge of the oldest basidiocarps. Marginal surface of mature pileus covered with agglutinated (never recurved), fibrillose hairs. Colour whitish to yellowish, the centre azonate, concolorous with the margin, the marginal part densely zonate with narrow watery zones (not so far towards the centre as in L. aquizonatus), the hairs whitish when young, yellow brown to dark brown in age, making the marginal surface bicolorous. Context thick, hard. Latex white, rapidly turning suphur yellow when exposed, organge in $\mathrm{KOH}$, acrid. Odour fruity, not so strong as in L. aquizonatus.

Lamellae thick, subdistant, sparsely forked near stipe, unevenly decurrent, whitish to alutaceous, lamellulae numerous.

Stipe $3.5-7 \mathrm{~cm}$ long, $2-3.5(-4.5) \mathrm{cm}$ thick, thickening upwards, hollow, hard, with very hard subradicating bulb at base, unpolished, usually covered by whitish tomentum, not scrobiculate, dry, coarsely hairy at base.

Spores $7-8.4 \times 5.4-6.6 \mu \mathrm{m}$, length/width ratio $1.21-1.38$, broadly ellipsoid, with a myloid ornamentation with long labyrinthine ridges, shorter fragments and isolated warts, not forming a reticulum, prominences up to $0.8 \mu \mathrm{m}$ high, plage distinct, rather large and broad.

Basidia 34-45 × 7-12 $\mu \mathrm{m}, 4$-spored. Macrocystidia fairly frequent, $40-65 \times 7-11 \mu \mathrm{m}$, ventricoserostrate, with the broadest point in the hymenium, projecting up to $30 \mu \mathrm{m}$, difficult to observe in the surface view of the gill (not seen in the type specimen, possibly collapsed in drying). Pseudocystidia 4-7 $\mu \mathrm{m}$ thick.

In Fennoscandia calcicolous, growing in dryish grass-herb forests and thickets with hardwoods and with or without conifers. Scattered or in groups, seldom gregarious. Temperate to hemiboreal, very rare in the southern and middle boreal zones. July to October.

Distribution and ecology

In Fennoscandia L. citriolens is an exacting and calci- colous species. In Finland it is rare and found only in the most fertile calcareous sites. Most of the localities were discovered after 1977 and the three older specimens were not available in the public herbarium or were wrongly identified. Thus all the records in the Finnish literature (Tuomikoski 1971, Ahti 1975, Ulvinen et al. 1981) of L. citriolens or L. cilicioides sensu Neuhoff refer to other species, mostly L. aquizonatus.

In Scandinavia L. citriolens is most frequent in the fertile areas of Uppland and Södermanland near Stockholm. Elswhere in Sweden only scattered occurrences are known, all of them in the areas of unmetamorphosed, calcareous, Cambro-Silurian bedrock. In Norway L. citriolens has not been found. More field work is needed to decide whether it occurs elsewhere in the southern part of Sweden or in Norway, or whether it has the same eastern distribution in Fennoscandia as the other species of the white group.

In Estonia L. citriolens seems to be commoner than in Fennoscandia, but there also it is evidently not as common as L. aquizonatus.

In Central Europe (except the mountain areas) $L$. citriolens is evidently the commonest species of the subsection Scrobiculati (cf. Neuhoff 1956, Pouzar 1968), as is confirmed by its hight percentage in the collections in PRM. In the British Isles it is rare (Cooke 1883, Phillips 1981). The South European records (e.g. Cetto 1979) needs confirmation.

L. citriolens is usually recorded from deciduous or mixed forests (ç. Neuhoff 1956). In Czechoslovakia (Pouzar 1968, Śmarda 1969) it grows in calcareous frondose woods with Quercus petraea, Carpinus betulus and Fagus sylvatica. In Fennoscandia the principal tree in its habitats seems to be Betula. In Grisslehamn, in NE Uppland, Sweden (Ky $78643 \mathrm{H}$ ), the species grew abundantly under Corylus avellana bushes in dryish open forest of Picea abies and Quercus robur.

The habitats in Fennoscandia are rather open, often park-line, dry or dryish grass-herb forests with a thin and discontinuous moss cover. The fruit bodies often grow on bare soil or the stipe grows from the mineral soil through the thin litter horizon. The species does not thrive in a thick moss cover or in paludified habitats.

L. citriolens is a temperate and hemiboreal fungus with a few outposts in the north. In addition to being located on calcareous bedrock, the northernmost occurrences are also often in sites with favourable, microclimates, on lake islets or capes, only some metres above the water's edge. In France, Kühner (1975) includes $L$. citriolens among the agarics of the alpine zone, but his interpretation of the zone may be different from that adopted here.

\section{Phenology}

In Fennoscandia L. citriolens has a very long fruiting season, beginning in late July and ceasing in mid-October (Fig. 17). It is not sensitive to occasional frosty nights.

\section{Discussion}

L. citriolens can be recognised by its robust appearance, hard context, short unpolished, hard stipe, very 

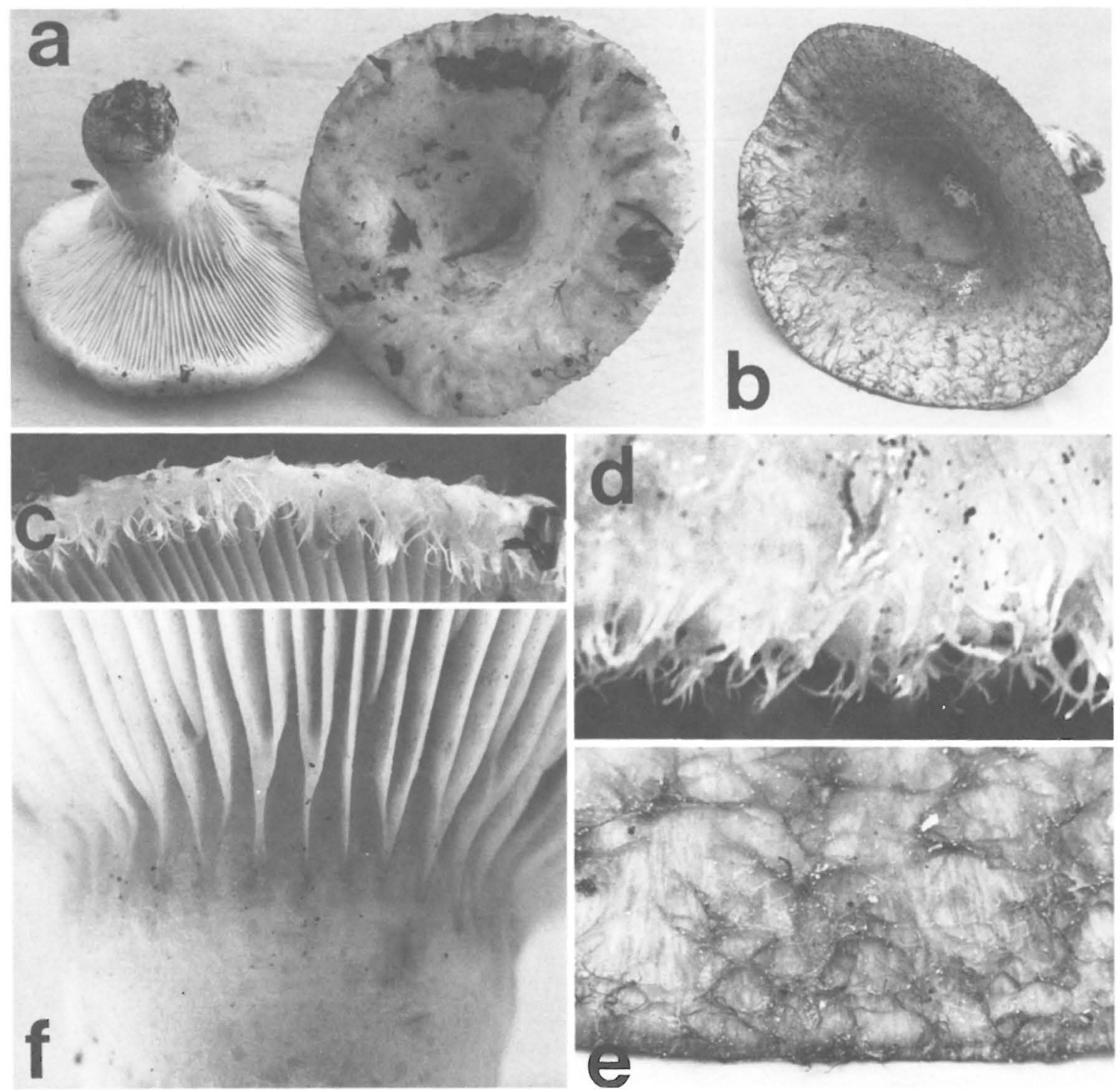

Fig. 15. Lactarius citriolens. - a, c, f) Ky 811292. - b, e) Ky 811505. - d) Korhonen 3998, photo M. Korhonen. - e) Agglutinated hairs on the marginal surface of an old basidiocarp.

hard basal buld and subdistant lamellae. The long fibrillose hairs of the pileus margin, becoming fuscous with age, and the characteristic marginal surface are easily seen in mature basidiocarps as well and in dry weather (in L. aquizonatus the scales are seen most clearly in young basidiocarps and in moist weather). The hairiness seems to vary, however. In Finnish material the hairs tend to be rather short and scanty, and nearly naked basidiocarps are not infrequent in the colonies. Such basidiocarps are easily mistaken for $L$. aquizonatus, if the underside of the fruit body is not checked. All the Swedish specimens seen by me had long hairs. This regional variation deserves study.
In Europe the interpretation of $\mathrm{v}$ the present species was long uncertain. In Britain, Cooke (1883) called this species $L$. cilicioides (Fr.), Fr., which was formerly, apparently in the original sense of Fries, used for a fungus of the L. torminosus group. He was followed by other British authors and by Neuhoff (1956). Pouzar (1968) returned to the former use of the name and described the present species as $L$. citriolens. At the same time he pointed out that $L$. crinitus Schaeffer and L. intermedius (Krombh.) Cooke, included in this species by Neuhoff (1956), do not belong here. Thus reports in the literature of these species are often misleading.

Hesler \& Smith (1960) recognized $L$. citriolens in 


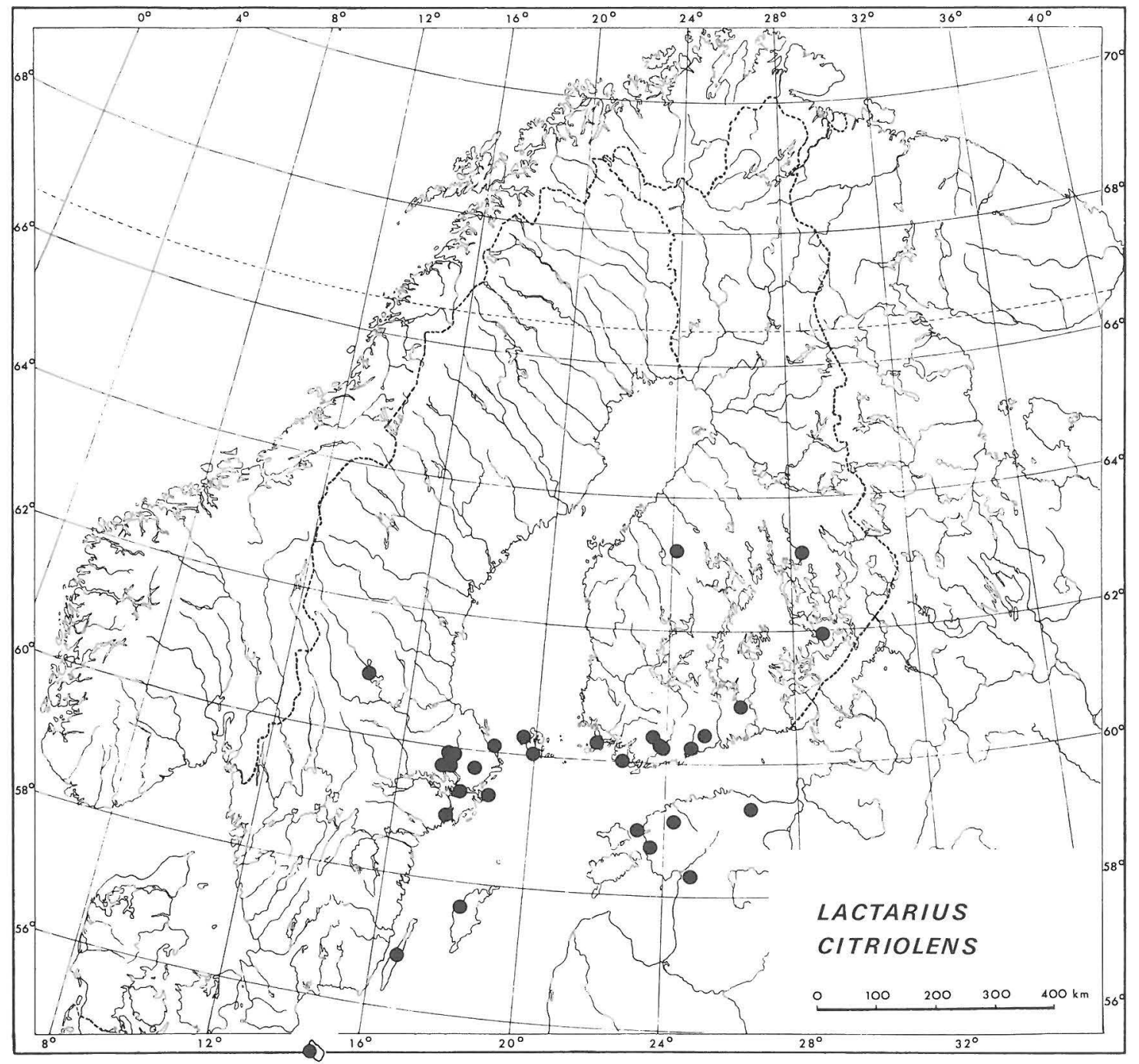

Fig. 16. Distribution of Lactarius citriolens in NW Europe according to the material examined.

North America under L. cilicioides (Fr.) Fr. sensu Neuhoff. In their monograph (1979: 545-547, 573) they returned the name $L$. cilicioides to the $L$. torminosus - pubescens complex and excluded L. citriolens from the North American Lactarius flora, but did not report in which species they included the material cited in 1960 . The only specimen examined by me s.n. L. cilioides (det A.H. Smith, not cited 1960) from North America is not related to L. citriolens Pouzar. Hesler \& Smith (1979) suspect that $L$. citriolens and $L$. delicatus Burl. may be the same taxon. In my opinion, $L$. citriolens is more clearly related to $L$. aquizonatus and $L$. resimus than to $L$. delicatus Burl. Records of $L$. cilicioides from North America by Peck (1885) and Burlingham $(1908,1910)$ refer to the L: torminosus -pubescens complex.
Specimens examined

Denmark. Bornholm: 1944 Möller (C).

Sweden. Gotland: 1948 Suber (S). Öland: Korhonen 3596 (H). Södermanland: 1953 Haglund \& Suber (S). Uppland: Belin (UPS), 1953 Haglund (S), Ky 79643, 79647 (H), 1947 Melderis (UPS), 1952 Rydberg \& Haglund (2 ex. S), Ryman 4339, 4959 (UPS), 1965 Suber (S). Dalarna: Ky 79498 (H).

Finland. Ahvenanmaa: Korhonen 3562, 3998 (H), 1978 Ulvinen (OULU). Varsinais-Suomi: Ky 801346, 801464, 801573, 811350, $811380(\mathrm{H}), 1961$ Toppari (2 ex. H), Vauras $160 \mathrm{~F}$ (TUR). Uusimaa: Korhonen 4164, 4902 (H), Ky 811305, $811306(\mathrm{H}), 1942$ Nyberg (H). Etelä-Häme: Ky $811569(\mathrm{H})$. Etelä-Savo: Ky $811505(\mathrm{H})$. Pohjois-Karjala: Korhonen $4152(\mathrm{H})$, Ky $80872(\mathrm{H})$. Keski-Pohjanmaa: Ky $811292(\mathrm{H})$

U.S.S.R. Estonian S.S.R.: 1957, 1967, 1980 Kalamees (TAA), 1963 Parts (TAA), 1979 Pihlik et al. (TAA). 


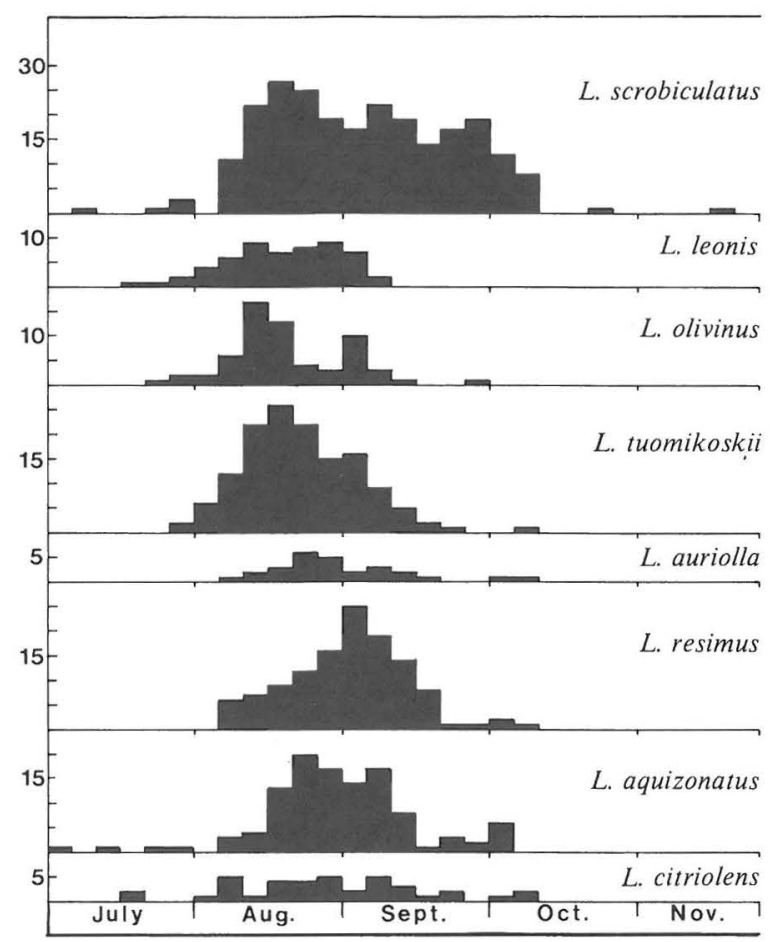

Fig. 17. Fruiting periods of the species above according to the specimens examined. $x$ axis: the season from 6.VII. to 28. XI. divided in pentads. y axis: number of specimens collected in each pentad.

\section{Synopsis of excluded taxa}

1. L. alnicola A.H. Smith in Hesler \& A.H. Smith, Brittonia 12: 319. 1960. Holotype: U.S.A. Idaho, Warm Lake, 5.VIII. 1958 A.H. Smith 59648 (MICH). Smith $46111(\mathrm{MICH})$ also examined. - See under L. scrobiculatus.

2. L. alnicola var, pitkinensis Hesler \& A.H. Smith, N. Amer. Lactarius: 302. 1979. Holotype: U.S.A. Colorado, Pitkin Co. prope Aschroft, 19.VIII.1975 A.H. Smith 85874 (MICH). - Not related to L. alnicola, but rather belongs to the subsection Piperites.

3. L. alnicola var. pungens Hesler \& A.H. Smith, N. Amer. Lactarius: 303. 1979. Holotype: U.S.A. Michigan, Marquette Co. Huron Mts. Club, prope Canyon Lake, 29. VIII. 1970

A.H. Smith 78673 (MICH). - See under L. scrobiculatus.

4. Agaricus cilicioides Fr., Syst. Mycol. I: 63. 1821. - See under L. citriolens.

5. L. cilicioides var. albus Peck, Ann. Rep. N.Y. State Mus. 38: 119. 1885. - Type not seen. The taxon belongs to the L. torminosus - pubescens complex.

6. L. delicatus Burl., Mem Torrey Bot. Club 14: 40. 1908. Holotype: U.S.A. North Carolina, 'Pink Beds', 17.VIII.1907 G.S. Burlingham 72 (NY). Also Beardslee 38131 (MICH) examined. - See under L. azuizonatus, L. citriolens.

7. L. gossypinus Hesler \& A.H. Smith, N. amer. Lactarius: 291. 1979. Holotype: U.S.A. Wyoming, Grand Teton National Park, Lizard Creek, 1.IX.1967 K. McKnight 10572 (BPI). - The infundibuliform, ochraceus pileus, short, unpolished, indistinctly spotted stipe and ellipsoid, reticulate spores show affinity ot the white group, especially $L$. resimus, but it is separated by the thick, cottony context and very narrow lamellae.
8. L. intermedius (Krombh.) Cooke, Hanb, British Fungi: 305. 1883. - In Central Europe the name is nowadays used of a yellow lowland species with a tomentose pileus margin and weakly differentiated pseudocystidioid macrocystidia, which is thus more closely related to L. scrobiculatus than to the boreal species treated here.

9. L. payettensis A.H. Smith in Hesler \& A.H. Smith var. payettensis, Brittonia 12: 324. 1960. Holotype: U.S.A. Idaho, Payette National Forest, Big Creek, 24. VIII.1958 A.H. Smith $60411(\mathrm{MICH})$. Also Smith $60586(\mathrm{MICH})$ examined. - See under L. olivinus.

10. L. payettensis var. canadensis A.H. Smith in Hesler \& A.H. Smith, Brittonia 12: 325. 1960. Holotype: Canada, Quepec, St. Anne-de-la-Pocatière, 6.IX.1959 A.H. Smith $61886(\mathrm{MICH}) .-$ See under L. olivinus.

11. L. pseudodelicatus A.H. Smith in Hesler \& A.H. Smith, Brittonia 12: 310. 1960. Holotype: U.S.A. Michigan, Douglas Lake, 31.VIII.1951 A.H. Smith 38368 (MICH). Also Weber 3933 examined. - See under L. aquizonatus.

12. L. scrobiculatus var. scrobiculatus sensu Hesler \& A.H. Smith 1960. Specimens Smith $24494(\mathrm{MICH})$ and Smith 48153 (TUR) examined. - See under L. scrobiculatus, $L$. tuomikoskii.

13. L. scrobiculatus var. canadensis (A.H. Smith) Hesler \& A.H. Smith, N. Amer. Lactarius: 297. 1979. - A combination of 10 and 12 . In addition to the specimens in 10 and 12 , Smith $74733(\mathrm{MICH})$ examined. The latter differs from the holotype and from 12 . Thus 13 includes at least three species. See L. scrobiculatus, L. leonis, L. olivinus.

14. L. scrobiculatus var. pubescens A.H. Smith in Hesler \& A.H. Smith, Brittonia 12: 323. 1960. Holotype: U.S.A. Michigan, Tahquamenon Falls State Park, 7.IX.1951 A.H. Smith 38436 (MICH). Smith 38594 (MICH) also examined. - See under L. scrobiculatus, L. aquizonatus.

15. L. subpaludosus Hesler \& A.H. Smith, N. Amer. Lactarius: 286. 1979. Holotype: U.S.A. Michigan, Chelsea, prope Cedar Lake, sub. Betulae, 1.X.1973 A.H. Smith 84673 (MICH). Smith 67347. (MICH) also examined. - This small, white, small-spored species is related to the L. torminosus - pubescens complex.

16. L. subresimus O.K. Miller, Arctic Alpine Mycol.: 131. 1982. Holotype: U.S.A. Alaska, Mile 106 Steese Hwy, Eagle Summit, 17. VIII.1979 O.K. Miller 18174 (VPI). - A clearly distinct species, which macroscopically somewhat resembles L. tuomikoskii, but is differentiated by the fairly small subglobose spores, and small slightly projecting macrocystidia.

Acknowledgements. I wish to thank Prof. Teuvo Ahti, Ph.D., for advice during the work and valuable suggestions regarding the manuscript. I am also indebted to Dr. Harri Harmaja for advice, to Mr. Mauri Korhonen for photographs and discussions, to Mrs. Pirjo Kytövuori, M.Agr. and For., for help with the field work, and to Mrs. Anna Damström, M.A., and Mrs. Marja Kaila, M.A., for the English and Latin revisions. 
严:

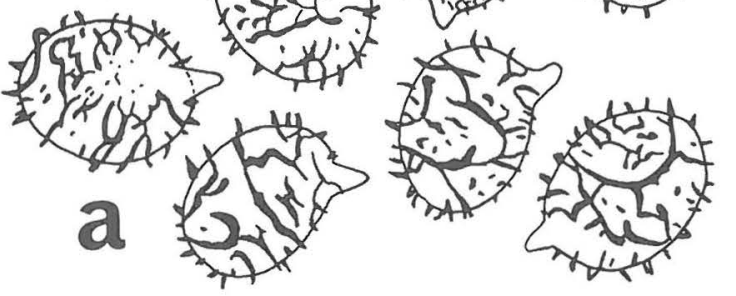

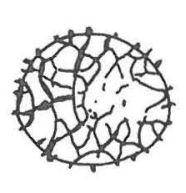

( b

20ivis

C

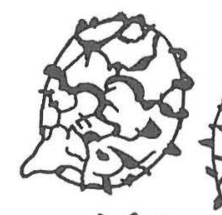

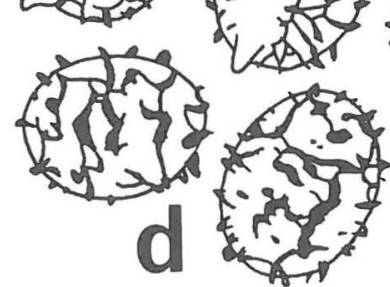

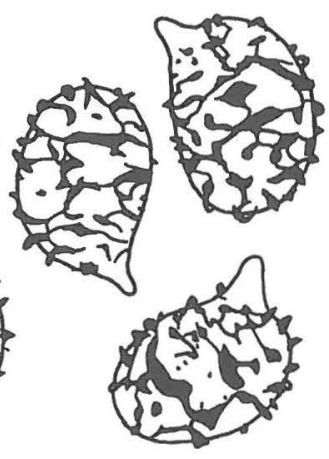

स⿺辶一

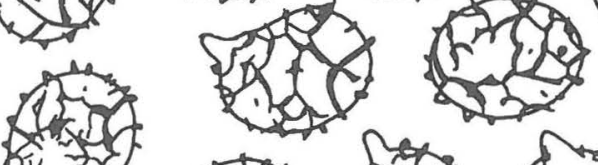

in
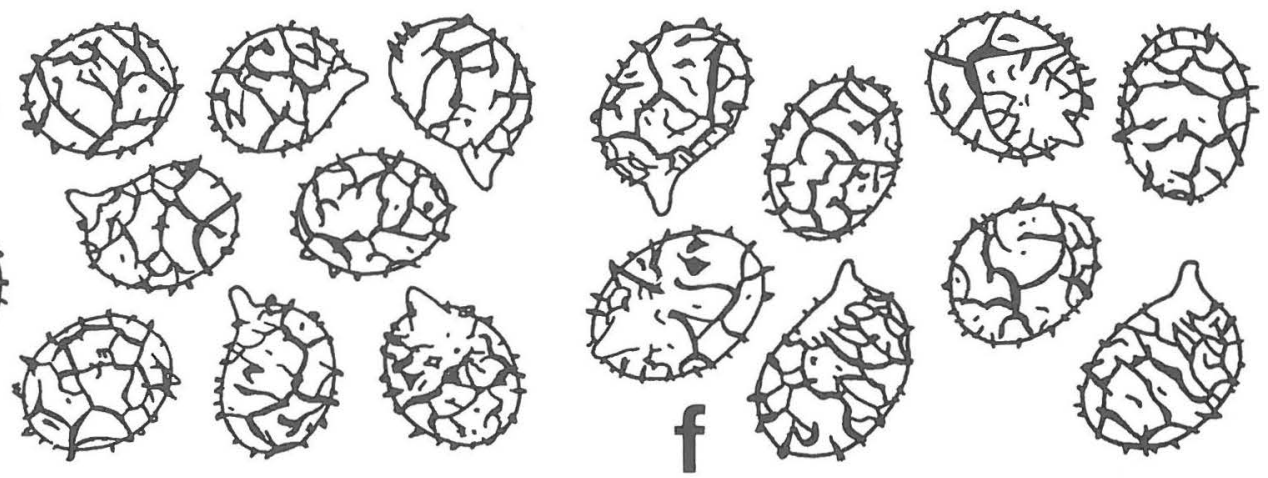

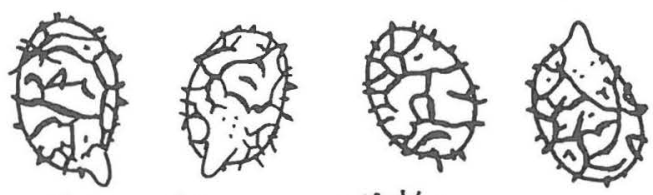

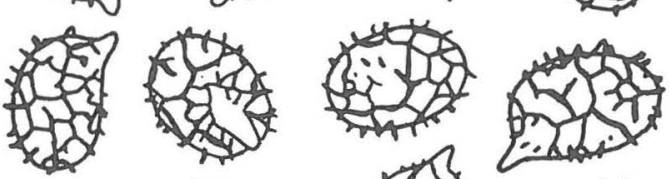

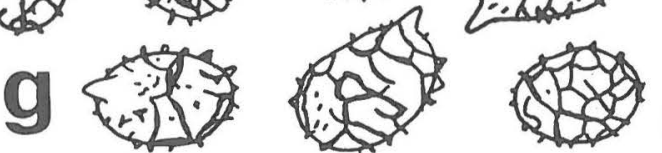
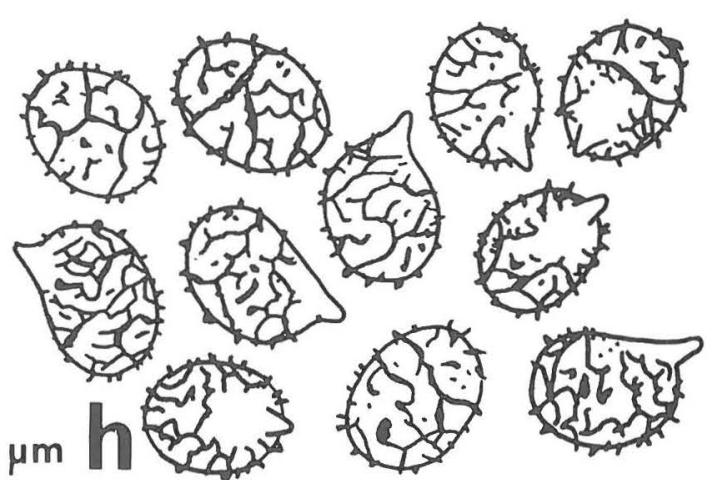

Figs. 18-19. Drawings and photographs of spores. - a) Lactarius scrobiculatus Ky 801232 , b) L. leonis Ky 81634 (holotype), c) L. olivinus Ky 81587 (holotype), d) L. tuomikoskii 1974 Tuomikoski (holotype), e) L. auriolla Ky 81638 (holotype), f) L. resimus Ky 811293, g) L. aquizonatus Ky 81934 (holotype), h) L. citriolens Ky 79498. Scale $\times 2000$. - Photo M. Korhonen. 


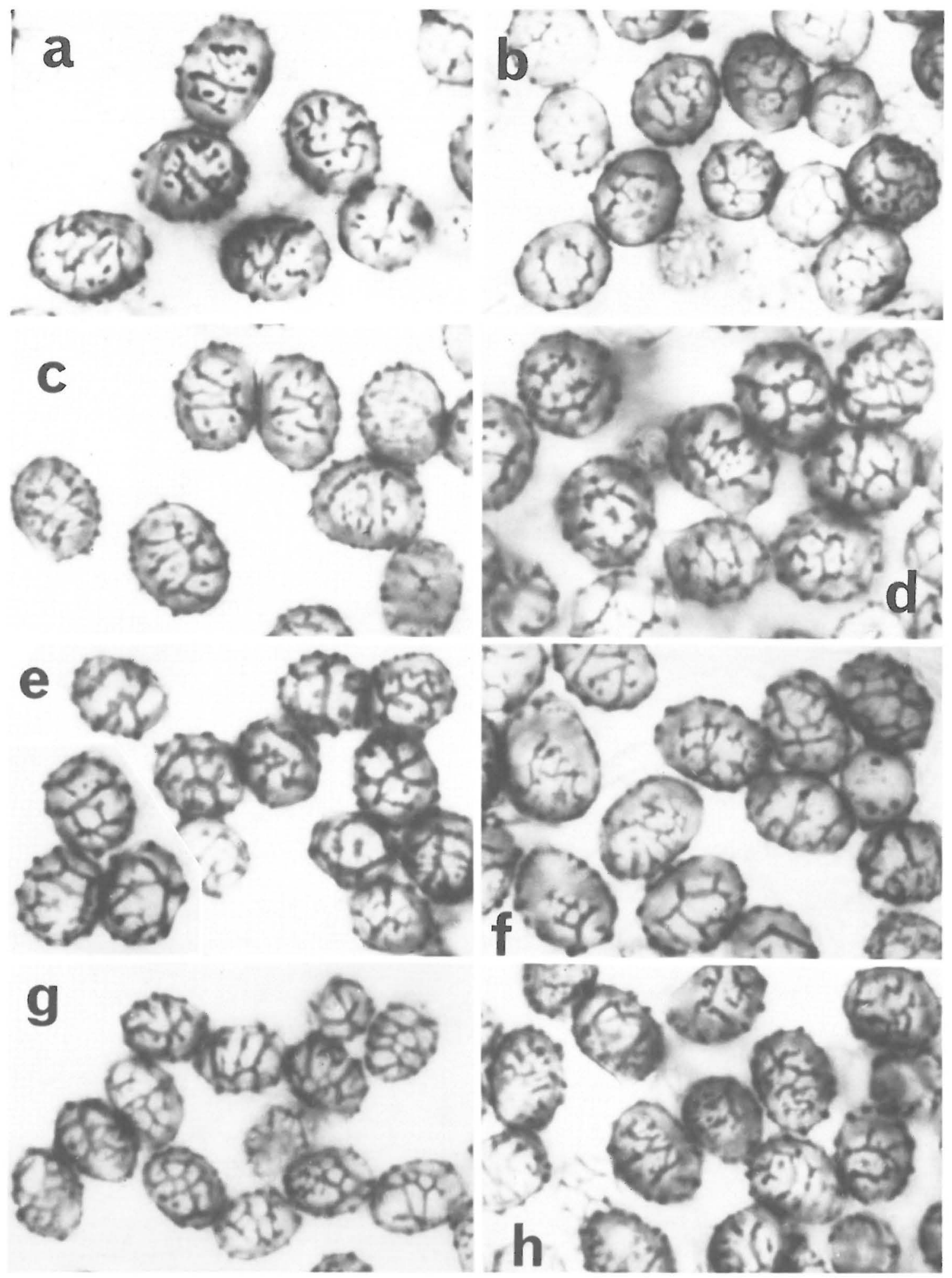




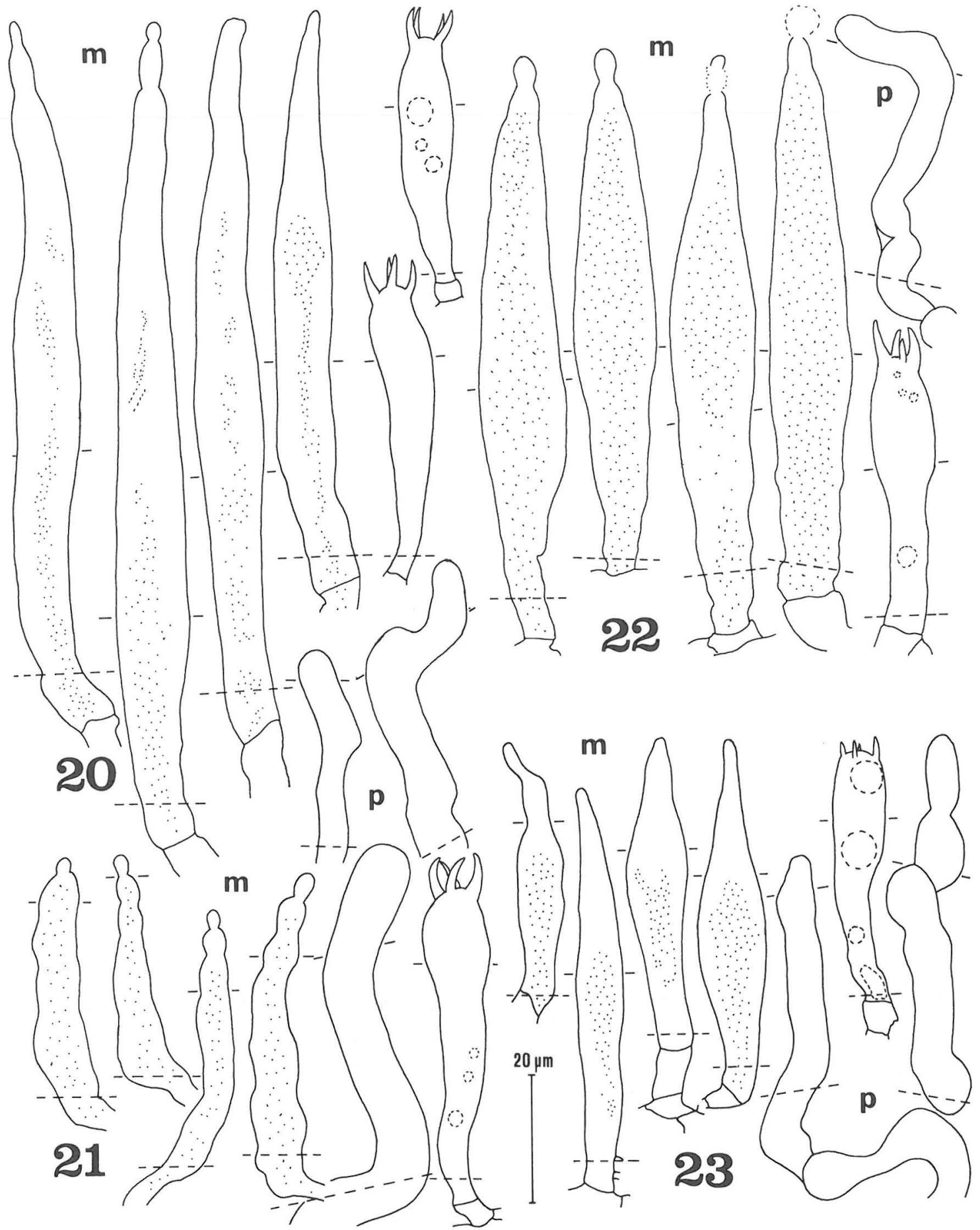

Figs. 20-27. Macrocystidia (m), pseudocystidia ( $p$ ) and basidia. The outer surface of the hymenium indicated with short lines, the inner surface with a broken line. Scale $\times 1000$. - 20: Lactarius leonis Ky 81634 (holotype). - 21: L. scrobiculatus Ky 801232. - 22: L. olivinus Ky 81587 (holotype). - 23: L. citriolens Ky 79498. - 24: L. auriolla Ky 81638 (holotype). - 25: L. tuomikoskii 1974 Tuomikoski (holotype). - 26: L. resimus Ky 811293. — 27: L. aquizonatus Ky 81934 (holotype). 


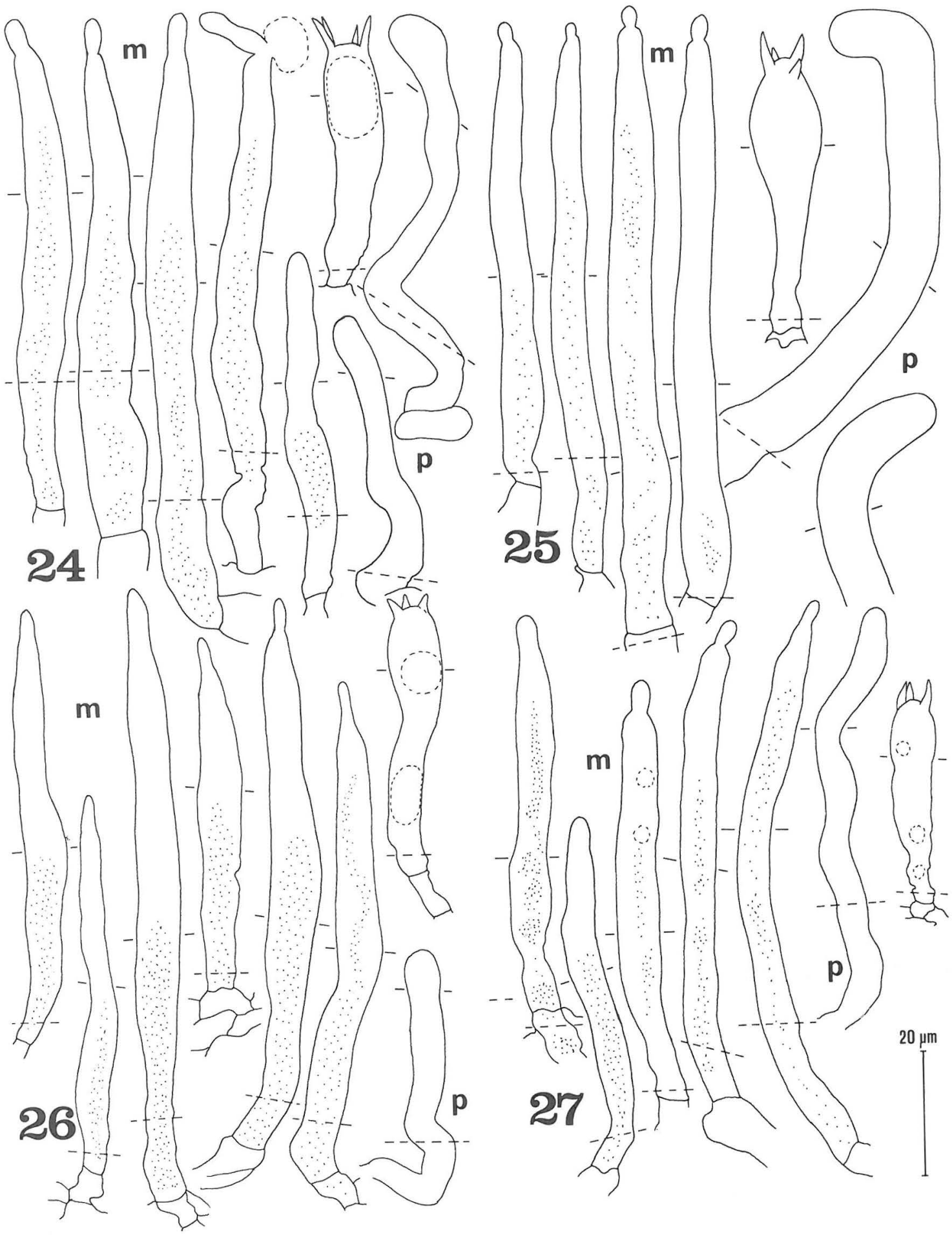

Figs. 20-27. Macrocystidia (m), pseudocystidia ( $p$ ) and basidia. The outer surface of the hymenium indicated with short lines, the inner surface with a broken line. Scale $\times 1000 .-20$ : Lactarius leonis Ky 81634 (holotype). - 21: L. scrobiculatus Ky 801232. - 22: L. olivinus Ky 81587 (holotype). - 23: L. citriolens Ky 79498. - 24: L. auriolla Ky 81638 (holotype). - 25: L. tuomikoskii 1974 Tuomikoski (holotype). - 26: L. resimus Ky 811293. - 27: L. aquizonatus Ky 81934 (holotype). 


\section{References}

Ahti, T. 1975: Rouskut - Lactarius. - In: Ulvinen, T. (ed.), Suursieniopas: 191-200. Helsinki.

Ahti, T., Hämet-Ahti, L. \& Jalas, J. 1968: Vegetation zones and their sections in northeastern Europe. - Ann. Bot. Fennici 5: 169-211.

Albertini, I.B. \& Schweiniz, L.D. 1805: Conspectus fungorum in Lusitaniae superioris agro niskiensi crescentium. - 376 pp., 12 pls. Lipsiae.

Bon, M. 1980: Clé monographique du genre Lactarius (Pers. ex Fr.) S.F. Gray. - Documents Mycol. 10: 1-85.

Bresadola, G. 1928: Iconographia mycologica 7. - Pls. 301-400. Mediolani.

Burlingham, G.S. 1908: A study of the Lactariae of the United States. - Mem. Torrey Bot. Club 14: 1-109.

- 1910: Lactaria Pers. - North American Flora 9: 172200.

Cetto, B. 1979: Der grosse Pilzführer 1-3. - 669+ $729+$ $635 \mathrm{pp}$. Trento.

Cooke, M.C. 1883: Handbook of British fungi. 2nd ed. $398 \mathrm{pp}$. London.

- 1888-1890: Illustrations of British fungi (Hymenomycetes) 7. - 10 pp., pls. 955-1114. London.

Dähncke, R.M. \& Dähncke, S.M. 1980: 700 Pilze in Farbfotos. - 686 pp. Stuttgart.

Fries, E. 1815: Observationes mycologicae 1. - 230 pp. Havniae.

- 1821: Systema mycologicum, sistens Fungorum ordines, genera et species, huc usque cognitas 1 . $-520 \mathrm{pp}$. Lundae.

- 1836-1838: Epicrisis systematicis mycologici, seu synopsis Hymenomycetum. - 610 pp. Upsaliae.

- 1863: Monographia Hymenomycetum Sueciae 2. - 355 pp. Upsaliae.

- 1877-1884: Icones selectae Hymenomycetum nondum delineatorum. - 104 pp., 200 pls. Holmiae \& Upsaliae.

Hesler, L.R. \& Smith, A.H. 1960: Studies of Lactarius 2. The North American species of sections Scrobiculus, Crocei, Theiogali and Vellus. - Brittonia 12: 306-350.

- 1979: North American species of Lactarius. - 841 pp. Ann Arbor.

Holmgren, P.K., Keuken, W. \& Schofield, E.K. 1981: Index herbariorum 1. The herbaria of the world. 7 th ed. Regnum Vegetabile 106: 1-452.

Hultén E. 1971: Atlas över växternas utbredning i Norden, fanerogamer och ormbunksväxter. - $531 \mathrm{pp}$. Stockholm.

Kalamees, K. 1979: Eesti riisikad. - 62 pp., 32 pls. Tallinn.

Korhonen, M. 1984: Suomen rouskut. - 223 pp. Helsinki.

Kornerup, A. \& Wanscher, J.H. 1961: Värien kirja. - 260 pp. Porvoo \& Helsinki. (English ed. 1963: Methuen handbook of colour. - London).

Krieglsteiner, J. 1984: Verbreitung und Ökologie 250 ausgewählter Blätterpilze in der Bundesrepublik Deutschland (Mitteleuropa). - Zeitschr. Mykol. 5: 69-302. Beihefte.

Krombholz, J.Y. 1843: Naturgetreue Abbildungen und Beschreibungen der essbaren, schädlichen und verdächlichen Schwämme 8. - 32 pp., pls. 55-62. Prag.

Kühner, R. 1975: Agaricales de la zone alpine. Genre Lactarius D.C. ex S.F. Gray. - Bull. Soc. Mycol. France 91: $5-69$.
Lange, J.E. 1935-1940: Flora agaricina danica 1-5. - 108 + 24 pp., 200 pls. Copenhagen.

Lange, M. 1964: Retkeilijän sieniopas. - 244 pp. Helsinki.

Lid, J. 1979: Norsk og svensk flora. -808 pp. Oslo.

Marchand, A. 1980: Champignons du nord et du midi 6 Lactaires et Pholiotes. - 290 pp. Barcelona.

Michael, E., Henning, B. \& Kreisel, H. 1983: Handbuch für Pilzfreunde 5. $-408 \mathrm{pp}$. Stuttgart.

Miller, O.K. Jr. 1982: Higher fungi in Alaskan subarctic tundra and taiga plant communities. - Arctic Alpine Mycol. First Int. Symp. Arcto-Alpine Mycol.: 123-149. Seattle \& London.

Mossberg, B., Nilsson, S. \& Persson, O. 1977: Svampar i naturen 2. $-132 \mathrm{pp}$. Stockholm

Neuhoff, W. 1956: Die Milchlinge (Lactarii). - Die Pilze Mitteleuropas IIb: $1-248,18$ pls. Bad Heilbrunn.

Peck, C.H. 1873: Descriptions of new species of fungi. Bull. Buffalo Nat. Sci. 1: 41-72.

- 1885: New York species of Lactarius. Report of the state botanist (for 1884). - Ann. Rep. N.Y. State Mus. 38 $111-133$

Phillips, R. 1981: Mushrooms and other fungi of Great Britain and Europe. $-288 \mathrm{pp}$. London.

Pilát, A. \& Ušák, O. 1979: Naše houby 2. - 345 pp. Praha.

Pomerleau, R. 1980: Flore des champignons au Quebec et régions limitrophes. - $653 \mathrm{pp}$. Ottava.

Pouzar, Z. 1968: Notes on some of our species of the genus Lactarius 2. - Ceská Mykol. 22: 20-23.

Ricken, A. 19i5: Die Blätterpilze (Agaricaceae) Deutschlands und der angegrenzenden Länder, besonders Oesterreichs und der Schweiz. - 480 pp., 112 pls. Leipzig.

Scopoli, I.A. 1772: Flora carniolica exhibens plantas Carnioliae indigenas et distributas, in classes, genera, species, varietates, ordinae Linneano 2. 2nd ed. $-496 \mathrm{pp}$. Vindobonae.

Schaeffer, J.C. 1774: Fungorum qui in Bavaria et Palatinatu circa Ratisbonam nascuntur, Icones 3. - Ratisbonae.

Šmarda, F. 1969: Die Verbreitung der Lactarius-Arten in den Waldgesellschaften Süd- und Westmährens. - Ceská Mykol. 23: 181-186.

Snell, W.H. \& Dick, E.A. 1971: A glossary of mycology. 2nd ed. - $181 \mathrm{pp}$. Cambridge, Mass.

Tuomikoski, R. 1943: Sortavalan seudun sienimaailmaa. Luonnon Ystävä 47: 178-179.

- 1952: Suomen rouskus (Lactarius). - Luonnon Tutkija 56: $75-85$.

- 1953: Die Lactarius-Arten Finnlands. - Karstenia 2: $9-25$.

- 1971 (ed.): Sienet värikuvina. 3nd ed. - 246 pp. Porvoo \& Helsinki.

Ulvinen, T., Ohenoja, E., Ahti, T. \& Alanko, P. 1981: A checklist of fungi (incl. Lichenes) of the Koillismaa (Kuusamo) biological province, NE Finland. - Oulanka Reports 2: $1-64$.

Vasil'eva, L.N. 1973: Agarikovye shlyapochnye griby (por. Agaricales) Primorskogo kraya. - $332 \mathrm{pp}$. Leningrad.

Watling, R. \& Gregory, N.M. 1977: Larger fungi from Turkey, Iran and neighbouring countries. - Karstenia 17: $59-72$.

Zuev, D. 1961: Dary russkogo lesa, griby i yagody. - 256 pp. Moskva. 